\title{
Virtual palaeontology: the effects of mineral composition and texture of fossil shell and hosting rock on the quality of X-ray microtomography (XMT) outcomes using Palaeozoic brachiopods
}

\author{
Sangmin Lee, G.R. Shi, Tae-Yoon S. Park, Jae-Ryong Oh, \\ Horng-Sheng Mii, and Mirinae Lee
}

\begin{abstract}
X-ray microtomography (XMT) has become a popular tool for detailed investigations of a diverse range of fossils. However, XMT has not always guaranteed a satisfactory result, as the resolution of XMT images critically depends on the contrast between the fossil and its hosting rock. In this paper, XMT was applied to 11 Palaeozoic brachiopod specimens selected from a range of sedimentary rocks in order to investigate the extent of effects of mineral composition and texture in the rock and fossil shell on the quality of XMT outcomes. Our study shows that sufficient contrast in mineral composition and texture between the brachiopod shell and its infilling material is required to reproduce high-quality XMT results. Specifically, brachiopod specimens with their original calcium carbonate shell, infilled mainly with quartz grains, appear to produce the best XMT results characterized by sharply defined shell internal structures. We also found that diagenesis is significant in determining the XMT quality. Diagenetic processes including silicification and recrystallization in the brachiopod shell and/or the infilling material generally tends to diminish the resolution of the XMT results, although this impact is considerably complicated by the degree and aspect of diagenesis. Another factor of minor significance concerns the presence of bioclasts scattered in the hosting sediment that potentially could be confused with genuine shell internal structures.
\end{abstract}

Sangmin Lee. School of Life and Environmental Sciences, Burwood Campus, Deakin University, 221 Burwood Highway, Burwood, VIC 3125, Australia. sangminlee76@gmail.com

G.R. Shi. School of Life and Environmental Sciences, Burwood Campus, Deakin University, 221 Burwood Highway, Burwood, VIC 3125, Australia. grshi@deakin.edu.au

Tae-Yoon S. Park. Division of Polar Earth-System Sciences, Korea Polar Research Institute, 26

Songdomirae-ro, Yeonsu-gu, Incheon 21990, Republic of Korea. typark@kopri.re.kr Jae-Ryong Oh. Division of Polar Earth-System Sciences, Korea Polar Research Institute, 26

Lee, Sangmin, Shi, G.R., Park, Tae-Yoon S., Oh, Jae-Ryong, Mii, Horng-Sheng, and Lee, Mirinae. 2017. Virtual palaeontology: the effects of mineral composition and texture of fossil shell and hosting rock on the quality of X-ray microtomography (XMT) outcomes using Palaeozoic brachiopods. Palaeontologia Electronica 20.2.3T: 1-25

palaeo-electronica.org/content/2017/1891-xmt-on-brachiopod-fossils

Copyright: @ June 2017 Society of Vertebrate Paleontology. This is an open access article distributed under the terms of the Creative Commons Attribution License, which permits unrestricted use, distribution, and reproduction in any medium, provided the original author and source are credited.

creativecommons.org/licenses/by/4.0/ 
Songdomirae-ro, Yeonsu-gu, Incheon 21990, Republic of Korea; and Polar Sciences, University of Science and Technology, Yuseong-gu, Daejeon 34113, Republic of Korea. ggilli@kopri.re.kr Horng-Sheng Mii. Department of Earth Sciences, National Taiwan Normal University, No. 88, Section 4, Ting-zhou Road, Taipei 11677, Taiwan, Republic of China. t44006@ntnu.edu.tw Mirinae Lee. Department of Earth and Environmental Sciences, Andong National University, Andong 36729, Republic of Korea. amsassia@anu.ac.kr

Keywords: computed tomography; internal structures; sedimentary infilling; diagenesis; three-dimensional reconstruction

Submission: 5 January 2017 Acceptance: 1 June 2017

\section{INTRODUCTION}

As computed tomographical techniques have spread into various fields of science in recent years, the adoption of these techniques, notably $X$ ray microtomography (XMT) and synchrotron radiation X-ray tomographic microscopy (SRXTM), to the study of fossils has also become increasingly popular, heralding a new era for virtual palaeontology (Sutton, 2008; Cunningham et al., 2014; Rahman and Smith, 2014; Sutton et al., 2014). A unique strength of these imaging techniques lies with its power to produce the complete set of serial sections of fossils in very high resolution while also protecting the integrity of the fossils by not causing any physical damage to them. Traditionally, palaeontologists had to use the mechanical thin-sectioning approach in that fossils embedded in rocks are cut, polished, and ground to make thin sections, and ultimately are destroyed. With the improvement of X-ray tomographic devices, several sophisticated types of computer software that support various image processing works have enabled scientists not only to visualize dissections of the scanned fossil material but also to reconstruct high-resolution three-dimensional (3-D) models of fossil morphology (Abel et al., 2012; Cunningham et al., 2014).

The interior of a brachiopod shell is critical for taxonomy. The fossil brachiopod valves may remain articulated even long after post-mortem transportation and burial, and in many cases morphological structures of shell interior are enclosed and hidden within the valves. Traditionally, the internal structures of fossil brachiopods, if not already available through either naturally preserved or human-prepared fossil moulds, have been observed by transverse serial thin sections through mechanical cutting. There are two wellknown caveats associated with the serial sectioning method. First and foremost, the method partially or completely destroys the specimens sectioned. Second, it only provides limited and incomplete information about shell growth and form, and such incomplete information has often been found misleading (St. Joseph, 1937; Westbroek, 1969; Sandy, 1986; Williams, 2002; Alvarez and Brunton, 2008). Although some computerbased software has been developed in recent years aiding the 3-D reconstruction models based on the conventional serial thin sectioning approach (Sutton et al., 2005; Schemm-Gregory and Sutton, 2010; Schemm-Gregory, 2014), these models are still incapable of producing complete 3-D configuration models of shell internal structures in a continuous manner.

With the rapid advance of modern imaging technology and associated software development for image processing, the aforementioned caveats can be considerably mitigated or even eliminated. Among the several tomographic techniques currently available, X-ray based methods have increasingly been piloted to fossil and modern brachiopods using both XMT (e.g., Hagadorn et al., 2001; Pakhnevich, 2007, 2009, 2010, 2011, 2014, 2017; Angiolini et al., 2010; Błażejowski et al., 2011; Gaspard, 2013; Seidel and Lüter, 2014; Halamski et al., 2015; Streng et al., 2016) and SRXTM (e.g., Perez-Huerta et al., 2009; Motchurova-Dekova and Harper, 2010; Kaloyan et al., 2014), with varying degrees of success in terms of image resolution and authenticity. One of the key challenges for the use of XMT and SRXTM for palaeontology is the choice of the fossil samples to be scanned, as the resolution of resultant scanned images critically depends on the degree of contrast in the mineralogy between the fossils and the materials that surround them or infill their inner cavities: generally, the greater the disparity in mineralogy between the fossils and the neighboring materials, the higher the resolution and authenticity of the reconstructed fossil internal structures. Pakhnevich (2010) applied XMT to both modern and fossil brachiopod shells, revealing that silicified 
or pyritized shells are well discriminated from carbonate rocks infilling the shells. Angiolini et al. (2010) also found that brachiopod shells filled by sandstone provide far greater resolution of XMT images than brachiopods enclosed within and filled with micritic limestone. Motchurova-Dekova and Harper (2010) applied SRXTM to two brachiopod specimens; one filled with fine-grained carbonate sediment (Paleogene) and the other with marl (Cretaceous). In spite of subtle differences in mineral composition between fossil shell and infilling sediment, the scanned results showed that the brachiopod internal structures are traceable, possibly due to greater differences in their textures.

It seems clear from these previous pilot studies that both the mineral composition and texture, of the fossil shells and their infillings, have a critical role in determining the quality and resolution of scanned fossil images. But how widespread this aspect would apply to other rock and fossil types and differing preservation/taphonomic conditions is still unknown. This study aims to investigate and reveal which factors affect the resolution and authenticity of XMT images most when applied to fossil brachiopod shells embedded in a range of rock types. For this purpose, this study provides sufficient practical XMT images and 3-D reconstruction models through XMT experiments on brachiopod fossils with a variety of combinations in the preserved shell and its infilling material. Based on the results, we illustrate the extent and variability of the effects of both mineral composition and texture of the fossil shells and neighboring materials on the quality and resolution of scanned fossil images.

\section{MATERIAL AND METHODS}

\section{X-ray Microtomography}

Eleven Palaeozoic (Devonian to Permian) brachiopod specimens were selected for internal X-ray tomographic scanning. The specimens were collected from nine different localities of Australia, Indonesia, China, USA, Canada, and Norway, with each representing a unique combination of mineral composition and texture between the brachiopod shell and its infilling sedimentary material. All but one of the specimens have been identified to genus level, and most of them have been assigned to species. With one exception all specimens have detailed geographic and stratigraphic (age) information (Table 1). All these specimens (thin sectioned or not) are currently housed in the Neil

TABLE 1. Summary of brachiopod taxa, locality and stratigraphic details of selected specimens for the XMT experiments.

\begin{tabular}{|c|c|c|c|c|c|}
\hline Sample & Species & Locality & Formation & Age & References \\
\hline GSC26406 & $\begin{array}{l}\text { Timaniella harkeri } \\
\text { Waterhouse in Bamber and } \\
\text { Waterhouse, } 1971\end{array}$ & $\begin{array}{l}\text { Grinnell Peninsula, } \\
\text { Devon Island, Canada }\end{array}$ & Assistance $\mathrm{Fm}$. & Roadian & $\begin{array}{l}\text { Waterhouse and } \\
\text { Waddington (1982) }\end{array}$ \\
\hline BS-1 & Spiriferina sp. & West Timor, Indonesia & Maubisse Fm. & Wuchiapingian & Charlton et al. (2002) \\
\hline BS-2 & $\begin{array}{l}\text { Stenoscisma timorense } \\
\text { (Hayasaka and Gan, 1940) }\end{array}$ & West Timor, Indonesia & Maubisse Fm. & Wuchiapingian & $\begin{array}{l}\text { Archbold and Bird } \\
\text { (1989) }\end{array}$ \\
\hline ML32 & $\begin{array}{l}\text { Cleiothyridina } \\
\text { baracoodensis (Etheridge, } \\
1903 \text { ) }\end{array}$ & $\begin{array}{l}\text { Carnarvon Basin, WA, } \\
\text { Australia }\end{array}$ & Callytharra Fm. & Artinskian & $\begin{array}{l}\text { Etheridge (1903), } \\
\text { Thomas (1958) }\end{array}$ \\
\hline $\mathrm{TeP}$ & $\begin{array}{l}\text { Tylothyris transversa } \\
\text { Roberts, } 1971\end{array}$ & $\begin{array}{l}\text { Bonaparte Basin, WA, } \\
\text { Australia }\end{array}$ & Enga Sandstone & Tournaisian & Roberts (1971) \\
\hline 3229 & Indospirifer sp. & Unknown & Unknown & Devonian & No records so far \\
\hline$C D$ & $\begin{array}{l}\text { Cyrtospirifer whitneyi (Hall, } \\
\text { 1858) }\end{array}$ & Rockford, lowa, USA & Lime Creek Fm. & Frasnian & Day (1988) \\
\hline S1 & Spiriferidae gen. sp. indet. & $\begin{array}{l}\text { Skansen, Spitsbergen, } \\
\text { Norway }\end{array}$ & $\begin{array}{l}\text { Wordiekammen } \\
\text { Fm. }\end{array}$ & Pennsylvanian & Nakamura et al. (1992) \\
\hline F8 & $\begin{array}{l}\text { Spiriferella loveni (Diener, } \\
\text { 1903) }\end{array}$ & $\begin{array}{l}\text { Kapp Starostin, } \\
\text { Spitsbergen, Norway }\end{array}$ & $\begin{array}{l}\text { Kapp Starostin } \\
\text { Fm. }\end{array}$ & Kungurian & $\begin{array}{l}\text { Gobbett (1964), } \\
\text { Nakamura et al. (1992) }\end{array}$ \\
\hline Q-1 & $\begin{array}{l}\text { Meekella sangzhiensis Liu } \\
\text { and Zhao in Liu et } \\
\text { al., } 1982\end{array}$ & $\begin{array}{l}\text { Liuyang County, Hunan } \\
\text { Province, China }\end{array}$ & Qixia Fm. & Kungurian & Liu et al. (1982) \\
\hline Q-2 & $\begin{array}{l}\text { Tyloplecta nankingensis } \\
\text { (Frech, 1911) }\end{array}$ & $\begin{array}{l}\text { Liuyang County, Hunan } \\
\text { Province, China }\end{array}$ & Qixia Fm. & Kungurian & Liu et al. (1982) \\
\hline
\end{tabular}


Archbold Earth Science Research Laboratory at Deakin University, Melbourne, Australia.

Every XMT experiment was executed with SkyScan 1172 system at the Dental Research Institute of Seoul National University, Seoul, Korea Rep. The selected brachiopod fossils were scanned with beam energy of $78-100 \mathrm{keV}$ and flux of $100-125 \mu \mathrm{A}$ at detector resolution of $24.90-$ $34.58 \mu \mathrm{m}$ per pixel. A $0.5 \mathrm{~mm}$ Al filter was applied in all the scanning and exposure time was either 316 or $474 \mathrm{~ms}$. The projection was performed for over $180^{\circ}$ with sample rotation step of $0.7-0.9^{\circ}$ and, consequently, projections between 209 and 275 were obtained from each specimen. Initially each specimen was scanned multiple times within the range of settings. Then the best imaging result for each specimen is selected. The detailed XMT setting for each specimen is summarized in Table 2.

The acquired projections were analyzed through the series of SKYSCAN software. Twodimensional (2-D) cross sections were obtained with DataViewer (v. 1.5.1), and the 3-D visualizations were made with CTVox (v. 3.0). The 2-D sectional images of each specimen were false colored with one of two different false-color lookup tables in DataViewer, in order to enhance the perception of details shown in the virtual sections. The 3-D models were all prepared in grey levels. In addition, as an exemplar, a detailed 3-D full reconstruction model of shell interiors (after the virtual removal of infilling sediment) was created for one specimen, Timaniella harkeri (GSC26406), through CTVol (v. 2.2).

\section{Petrographic and Compositional Analysis}

Subsequent to the XMT analysis, either the scanned specimen or an additionally chosen brachiopod specimen for each species was prepared for studying the mineralogical composition and texture of the brachiopod shell and its infilling material. These selected specimens were embedded in preevacuated epoxy, then thin sectioned transversely (parallel to the shell maximum width line) at the middle of shell at the Andong National University, Andong, Korea Rep. All thin sections were petrographically examined to detail the lithology and mineral contents of both the brachiopod shells and their infillings. The detailed chemical composition of shell and enclosed material in each thin section was obtained using Energy Dispersal Spectrometry (EDS) at the Korea Polar Research Institute, Incheon, Korea Rep. Additionally, cathodoluminescence $(C L)$ analysis for all thin sections was per- formed using a Leica DM LP model petrographic microscope with a CAMBRIDGE Model CLmk3A stage $(7 \mathrm{kV}, 250 \mu \mathrm{A})$ at the National Taiwan Normal University, Taiwan, R.O.C., in order to evaluate the diagenetic feature of brachiopod shells (Popp et al., 1986; Grossman et al., 1993, 2008).

\section{RESULTS}

Our XMT results display a wide spectrum of variations in image quality and resolution, changing from very high visibility to non-recognition with respect to the isolation of shell internal structures from adjacent sediment and cement (Table 2). The detailed mineralogical/chemical examinations for brachiopod shells and their enclosed materials also revealed a variety of compositional combinations (Tables 2-3, Figures 1-2). Further, the results of CL analysis suggest considerable differences among the examined specimens (Table 2, Figures 1-2).

The mineralogical compositions of brachiopod shells are simply divided into calcite and silica, whereas those of infilling materials yield more diverse categories including limestone, mixed carbonate-siliciclastic, and fully siliciclastic or silicified rocks (Tables 2-3). However, for the convenience of explanation and comparison, we have divided the infilling materials into three types: highly siliceous, carbonate, and mixed carbonate-siliciclastic. Below each XMT result is described for each of the four different compositional associations (combinations) between fossil shells and their infillings.

\section{Carbonate Shell with Highly Siliceous Infilling}

Two specimens from our experiments belong to this association. Timaniella harkeri Waterhouse in Bamber and Waterhouse, 1971 (GSC26406) retains the original calcite shell and infilling siliciclastic sediment, whereas both the shell and infilling cement of Stenoscisma timorense (Hayasaka and Gan, 1940) (BS-2) have suffered from diagenetic alteration via recrystallization and silicification. The overall quality of XMT results for these two specimens are relatively high, and shell internal structures are mostly recognizable.

The X-ray scanning result of Timaniella harkeri (GSC26406) provides the best illustrations of our XMT experiments. Its 2-D sliced images present a very sharp separation between the brachiopod shell and infilling sediment in the entire section. The apical region of the ventral valve is shown to have been strongly thickened by secondary shell material, and its teeth are also largely thickened (Figure 3.3-5, 3.15, 3.18-20). The wellpreserved spiralia with 17 whorls each side is 
TABLE 2. Summary of XMT setting, nature of brachiopod shells and their infillings, CL results of brachiopod shells, and quality of XMT images.

\begin{tabular}{|c|c|c|c|c|c|c|c|c|c|c|}
\hline Sample & $(\mathrm{keV})$ & $(\mu \mathrm{A})$ & 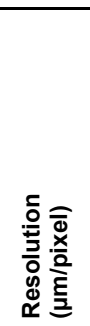 & 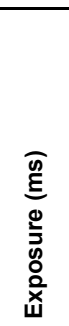 & 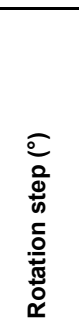 & 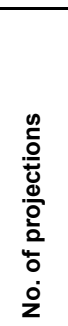 & 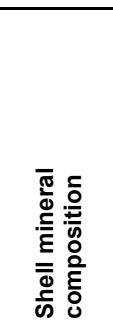 & 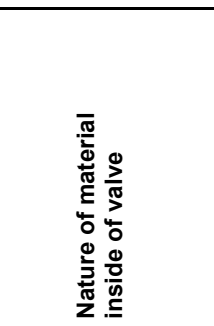 & 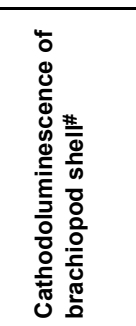 & $\begin{array}{l}\text { Degree of visibility of } \\
\text { shell internal structures } \\
\text { in XMT images }\end{array}$ \\
\hline GSC26406* & 89 & 112 & 31.82 & 316 & 0.70 & 271 & calcite & sandstone & $\begin{array}{l}\mathrm{NL} \\
\text { partially } \\
\mathrm{SL}\end{array}$ & $\begin{array}{l}\text { All internal shell structures } \\
\text { distinctly defined; Figures } \\
3,13,14\end{array}$ \\
\hline BS-1 & 85 & 118 & 26.98 & 316 & 0.70 & 275 & calcite & calcite cement & $S L$ & $\begin{array}{l}\text { Dental structures and } \\
\text { median septum well } \\
\text { recognized; Figure } 7\end{array}$ \\
\hline BS-2* & 78 & 125 & 34.58 & 474 & 0.90 & 209 & calcite & quartz cement & $\mathrm{L}$ & $\begin{array}{l}\text { Dental structures } \\
\text { (spondylium) recognized; } \\
\text { Figure } 4\end{array}$ \\
\hline ML32 & 100 & 100 & 24.90 & 316 & 0.90 & 214 & calcite & $\begin{array}{l}\text { mixed } \\
\text { carbonate- } \\
\text { silicate }\end{array}$ & SL & $\begin{array}{l}\text { Shell articulation and } \\
\text { cardinal structure } \\
\text { recognized; Figure } 5\end{array}$ \\
\hline $\mathrm{TeP}^{*}$ & 88 & 112 & 31.82 & 316 & 0.70 & 271 & calcite & $\begin{array}{l}\text { mixed } \\
\text { carbonate- } \\
\text { silicate }\end{array}$ & $\begin{array}{l}\mathrm{NL} \\
\text { partially } \\
\mathrm{SL}\end{array}$ & $\begin{array}{l}\text { Dental structures poorly } \\
\text { detected, spiralia partly } \\
\text { recognized; Figure } 6\end{array}$ \\
\hline $3229^{*}$ & 78 & 125 & 34.58 & 474 & 0.70 & 269 & calcite & lime mudstone & SL & $\begin{array}{l}\text { Dental structures well } \\
\text { defined, but having } \\
\text { possible mock structures; } \\
\text { Figure } 8\end{array}$ \\
\hline$C D^{*}$ & 88 & 112 & 32.85 & 474 & 0.90 & 209 & calcite & wackestone & $\mathrm{L}$ & $\begin{array}{l}\text { Dental structures weakly } \\
\text { detected; Figure } 9\end{array}$ \\
\hline S1 & 100 & 100 & 34.58 & 474 & 0.90 & 209 & calcite & packstone & $\begin{array}{l}\text { NL, } \\
\text { partly SL }\end{array}$ & $\begin{array}{l}\text { Dental structures not } \\
\text { sharply bounded, but } \\
\text { distinctly recognized; } \\
\text { Figure } 10\end{array}$ \\
\hline F8* & 100 & 100 & 34.58 & 474 & 0.90 & 209 & calcite & grainstone & $\begin{array}{l}\mathrm{SL}, \\
\text { partially } \\
\mathrm{L}\end{array}$ & $\begin{array}{l}\text { No traces of internal } \\
\text { structures }\end{array}$ \\
\hline$Q-1^{*}$ & 80 & 124 & 34.58 & 474 & 0.90 & 209 & silica & $\begin{array}{l}\text { microcrystalline } \\
\text { quartz }\end{array}$ & & $\begin{array}{l}\text { Dental structures poorly } \\
\text { and partly recognized; } \\
\text { Figure } 11\end{array}$ \\
\hline Q-2 & 80 & 124 & 34.58 & 474 & 0.70 & 269 & silica & quartz cement & & $\begin{array}{l}\text { Cardinal structures and } \\
\text { muscle scars distinctly } \\
\text { defined; Figure } 12\end{array}$ \\
\hline
\end{tabular}

${ }^{*}$ An additional specimen has been thin sectioned for $C L$ analysis.

\#NL, SL and L indicate nonluminescent, slightly luminescent and luminescent, respectively.

clearly shown to extend significantly in posterolateral direction (Figure 3.4-10, 3.13-22, 3.26). Serial slices in the sagittal plane indicate that the posterior region of the ventral valve is strongly thickened compared to the much thinner dorsal valve and the anterior region of the ventral valve (Figure 3.1822). Both the thin sections and EDS results show that the brachiopod shell is made up of well-pre- served calcium carbonate, and the cavity between valves is infilled with fine sandstone (Table 3 , Figure 1.1-4). The brachiopod shell itself is highly dense and has retained its original mineralogical composition, whereas the enclosed sediment is mainly composed of unconsolidated quartz grains (around $\quad 1 / 10 \mathrm{~mm}$ in diameter) with some iron oxides (hematite). Its CL images display a non- 
TABLE 3. Summary of EDS results, showing the elemental composition in brachiopod shell and infilling of each specimen.

\begin{tabular}{|c|c|c|c|c|c|c|c|c|c|c|c|}
\hline \multirow[b]{2}{*}{ Sample } & \multirow[b]{2}{*}{ EDS experiment area } & \multicolumn{10}{|c|}{ Composition of element (formula) (\%) } \\
\hline & & $\begin{array}{c}\mathrm{C} \\
\left(\mathrm{CO}_{2}\right)\end{array}$ & $\begin{array}{c}\mathrm{Ca} \\
(\mathrm{CaO})\end{array}$ & $\begin{array}{c}\mathrm{Si} \\
\left(\mathrm{SiO}_{2}\right)\end{array}$ & $\begin{array}{c}\mathrm{Mg} \\
\text { (MgO) }\end{array}$ & $\begin{array}{c}\mathrm{Al} \\
\left(\mathrm{Al}_{2} \mathrm{O}_{3}\right)\end{array}$ & $\begin{array}{c}\mathrm{S} \\
\left(\mathrm{SO}_{3}\right)\end{array}$ & $\begin{array}{c}\mathrm{K} \\
\left(\mathrm{K}_{2} \mathrm{O}\right)\end{array}$ & $\begin{array}{c}\mathrm{Mn} \\
(\mathrm{MnO})\end{array}$ & $\begin{array}{c}\mathrm{Fe} \\
(\mathrm{FeO})\end{array}$ & others \\
\hline \multirow{3}{*}{$\begin{array}{l}\text { GSC26 } \\
406^{*}\end{array}$} & Brachiopod shell & 59.02 & 40.98 & & & & & & & & \\
\hline & $\begin{array}{l}\text { Major grain in infilling } \\
\text { sediment }\end{array}$ & 39.90 & & 60.10 & & & & & & & \\
\hline & $\begin{array}{l}\text { Minor grain in infilling } \\
\text { sediment }\end{array}$ & 42.75 & 1.66 & 2.37 & & & & & & 53.22 & \\
\hline \multirow[t]{2}{*}{ BS-1 } & Brachiopod shell & 58.14 & 41.86 & & & & & & & & \\
\hline & Infilling cement & 55.34 & 44.66 & & & & & & & & \\
\hline \multirow[t]{2}{*}{ BS-2* } & Brachiopod shell & 53.25 & 43.94 & 1.53 & & & & & & 0.22 & 1.06 \\
\hline & Infilling cement & 33.06 & & 66.94 & & & & & & & \\
\hline \multirow[t]{4}{*}{ ML32 } & Brachiopod shell & 54.50 & 45.50 & & & & & & & & \\
\hline & $\begin{array}{l}\text { Major grain in infilling } \\
\text { sediment }\end{array}$ & 27.27 & & 72.73 & & & & & & & \\
\hline & $\begin{array}{l}\text { Minor grain in infilling } \\
\text { sediment }\end{array}$ & 37.85 & & 8.89 & 2.45 & 5.63 & & & & 45.19 & \\
\hline & Infilling micrite & 43.23 & 55.51 & & 1.25 & & & & & & \\
\hline \multirow[t]{2}{*}{$\mathrm{TeP}^{*}$} & Brachiopod shell & 57.14 & 41.64 & & & & 0.33 & & & & 0.89 \\
\hline & Infilling material (by area) & 49.07 & 31.67 & 13.27 & 0.55 & 2.75 & & 0.78 & 0.21 & 1.70 & \\
\hline \multirow[t]{2}{*}{$3229^{*}$} & Brachiopod shell & 61.42 & 37.13 & & 0.38 & 0.40 & 0.66 & & & & \\
\hline & Infilling sediment & 54.35 & 38.30 & 3.72 & 0.45 & 1.09 & & 0.32 & & 0.91 & 0.86 \\
\hline \multirow[t]{2}{*}{$C D^{*}$} & Brachiopod shell & 51.48 & 46.68 & & & & 0.62 & & & & 1.21 \\
\hline & Infilling sediment & 44.15 & 42.93 & 7.29 & 0.99 & 1.87 & 0.40 & 0.62 & & 0.82 & 0.93 \\
\hline \multirow[t]{3}{*}{ S1 } & Brachiopod shell & 51.44 & 48.56 & & & & & & & & \\
\hline & $\begin{array}{l}\text { Major grain in infilling } \\
\text { sediment }\end{array}$ & 59.39 & 40.61 & & & & & & & & \\
\hline & $\begin{array}{l}\text { Thin layer between shell and } \\
\text { infilling }\end{array}$ & 47.06 & 2.86 & 50.08 & & & & & & & \\
\hline \multirow[t]{2}{*}{ F8* } & Brachiopod shell & 55.30 & 38.80 & & & 0.45 & 0.57 & & & & 0.87 \\
\hline & Infilling sediment (by area) & 59.72 & 23.82 & 10.95 & 3.66 & 0.72 & & & & 1.13 & \\
\hline \multirow[t]{2}{*}{$Q-1^{*}$} & Brachiopod shell & 35.17 & & 63.61 & & 0.25 & & & & & 0.97 \\
\hline & Infilling cement & 35.94 & & 63.68 & & & & & & & 0.39 \\
\hline \multirow[t]{3}{*}{ Q-2 } & $\begin{array}{l}\text { Major part of brachiopod } \\
\text { shell }\end{array}$ & 34.76 & & 65.24 & & & & & & & \\
\hline & $\begin{array}{l}\text { Minor part of brachiopod } \\
\text { shell }\end{array}$ & 52.01 & & 29.37 & 18.62 & & & & & & \\
\hline & Infilling cement & 33.96 & & 66.04 & & & & & & & \\
\hline
\end{tabular}

${ }^{*}$ An additional specimen has been thin sectioned for EDS analysis.

cathodoluminescent shell (Figure 1.2) partially with slightly luminenscent regions (Figure 1.4), suggesting that the shell has been little altered by diagenesis (Grossman et al., 1993, 2008; Barbin and Gaspard, 1995; Tomašových and Farkaš, 2005).

The XMT sliced images of Stenoscisma timorense (BS-2) display a relatively distinct separation between the brachiopod shell and infilling cement, although the boundary becomes blurred anteriorly. In addition, the spondylium, a typical dental structure on the ventral floor of this genus, is more clearly shown both in the sliced images (Figure 4.2-6, 4.11-16, 4.20-21) and its 3-D reconstructions (Figure 4.26-27). However, no traces of cardinal structures on the dorsal valve floor are recognizable, most probably due to non-preserva- 

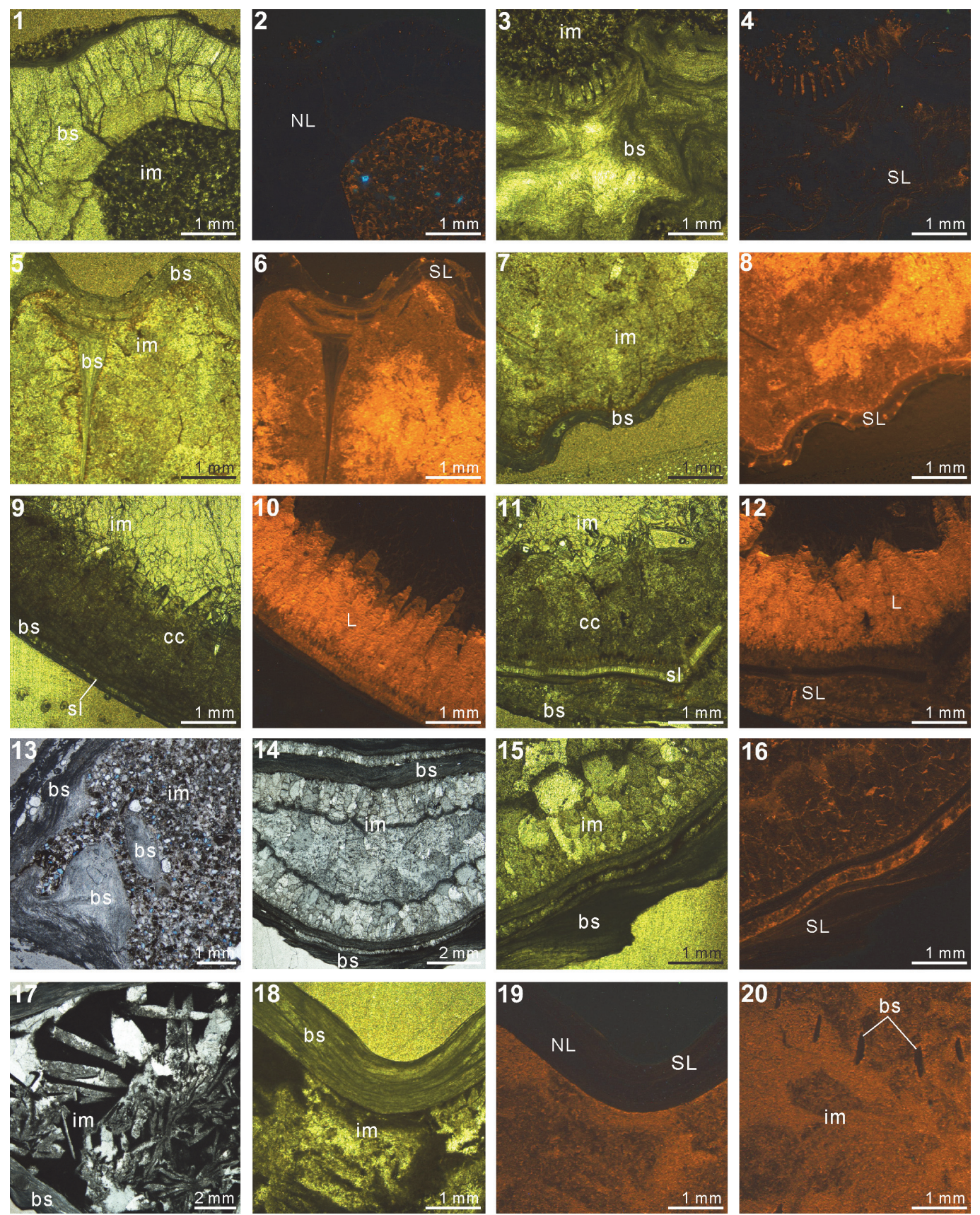

FIGURE 1. Thin section and cathodoluminescence (CL) photomicrographs: Timaniella harkeri (GSC26406) (1-4), Spiriferina sp. (BS-1) (5-8), Stenoscisma timorense (BS-2) (9-12), Cleiothyridina baracoodensis (ML32) (13-16) and Tylothyris transversa (TeP) (17-20). 1-2, transmitted light (TL) (1) and corresponding CL images (2) of nonluminescent shell and infilling sediment composed of fine sand grains. 3-4, TL (3) and CL (4) images of nonluminescent associated with partially luminescent shell in the cardinal area of dorsal valve. 5-8, TL $(5,7)$ and $C L(6,8)$ images of nonluminescent associated with partially luminescent shell and luminescent infilling cement. 9-12, TL $(\mathbf{9}, \mathbf{1 1})$ and $C L(\mathbf{1 0}, \mathbf{1 2})$ images of luminescent shell with thin silicified layers and recrystallization along inner wall of brachiopod shell. 13, plane-polarized light (PPL) image of the original infilling sediment composed of calcareous sands. 14, PPL image showing the section of infilling cement. 15-16, TL (15) and CL (16) images of slightly luminescent shell. 17, PPL image of infilling comprising lime mud, calcite cement and relatively large, radially arranged, siliceous crystals. 18-19, TL (18) and $C L(19)$ images of nonluminescent associated with partially luminescent shell. 20, CL image showing the section of nonluminescent internal shell structure (spiralia) preserved within infilling (This structure is hardly recognized in the TL image). Abbreviations: bs, brachiopod shell; im, infilling material; sl, silicified layer; cc, calcite crystal; NL, nonluminescent; SL, slightly luminescent; L, luminescent. 

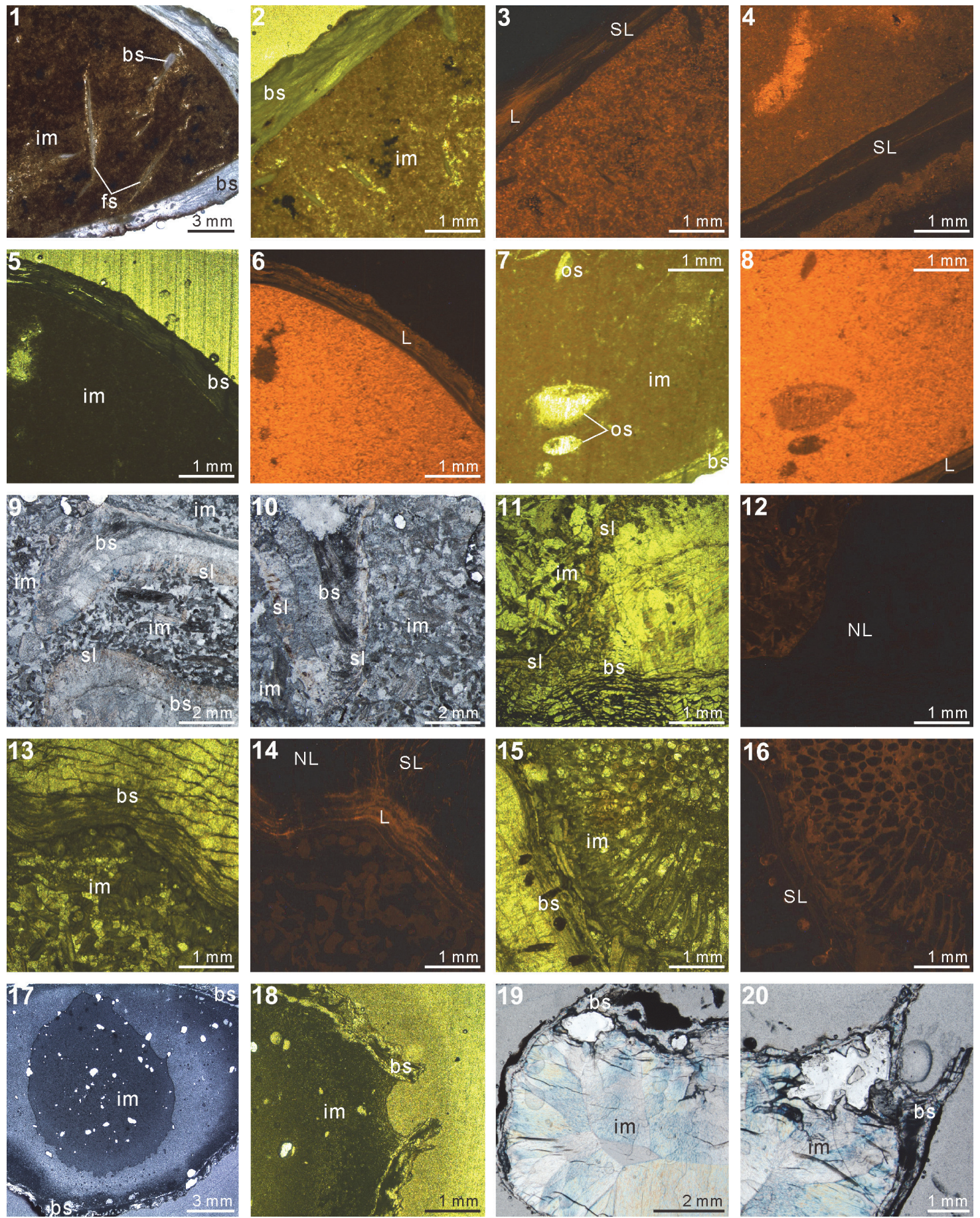

FIGURE 2. Thin section and cathodoluminescence (CL) photomicrographs: Indospirifer sp. (3229) (1-4), Cyrtospirifer whitneyi (CD) (5-8), Spiriferidae gen. sp. indet. (S1) (9-12), Spiriferella loveni (F8) (13-16), Meekella sangzhiensis (Q1) (17-18) and Tyloplecta nanjingensis (Q-2) (19-20). 1, plane-polarized light (PPL) image of infilling micrite and shell fragments scattered. 2-3, transmitted light (TL) (2) and corresponding $C L$ (3) images of luminescent shell. 4, CL image showing slightly luminescent shell. 5-8, $\operatorname{TL}(5,7)$ and $\operatorname{CL}(6,8)$ images of both luminescent shell and infilling sediment. 9-10, PPL images of brachiopod shell, infilling packstone and thin silicified layer along their boundary. 1112, TL (11) and CL (12) images of nonluminescent shell. 13-16, TL $(13,15)$ and $C L(14,16)$ images showing a variety of shell luminescence and infilling sediment composed of calcitic skeletal grains (bryozoan in 15 and 16). 17-20, PPL $(\mathbf{1 7}, \mathbf{1 9}, \mathbf{2 0})$ and TL $(\mathbf{1 8})$ images of both silicified shells and infillings. Abbreviations: bs, brachiopod shell; im, infilling material; fs, fragmented shell; os, other shell material; sl, silicified layer; NL, nonluminescent; SL, slightly luminescent; $\mathrm{L}$, luminescent. 


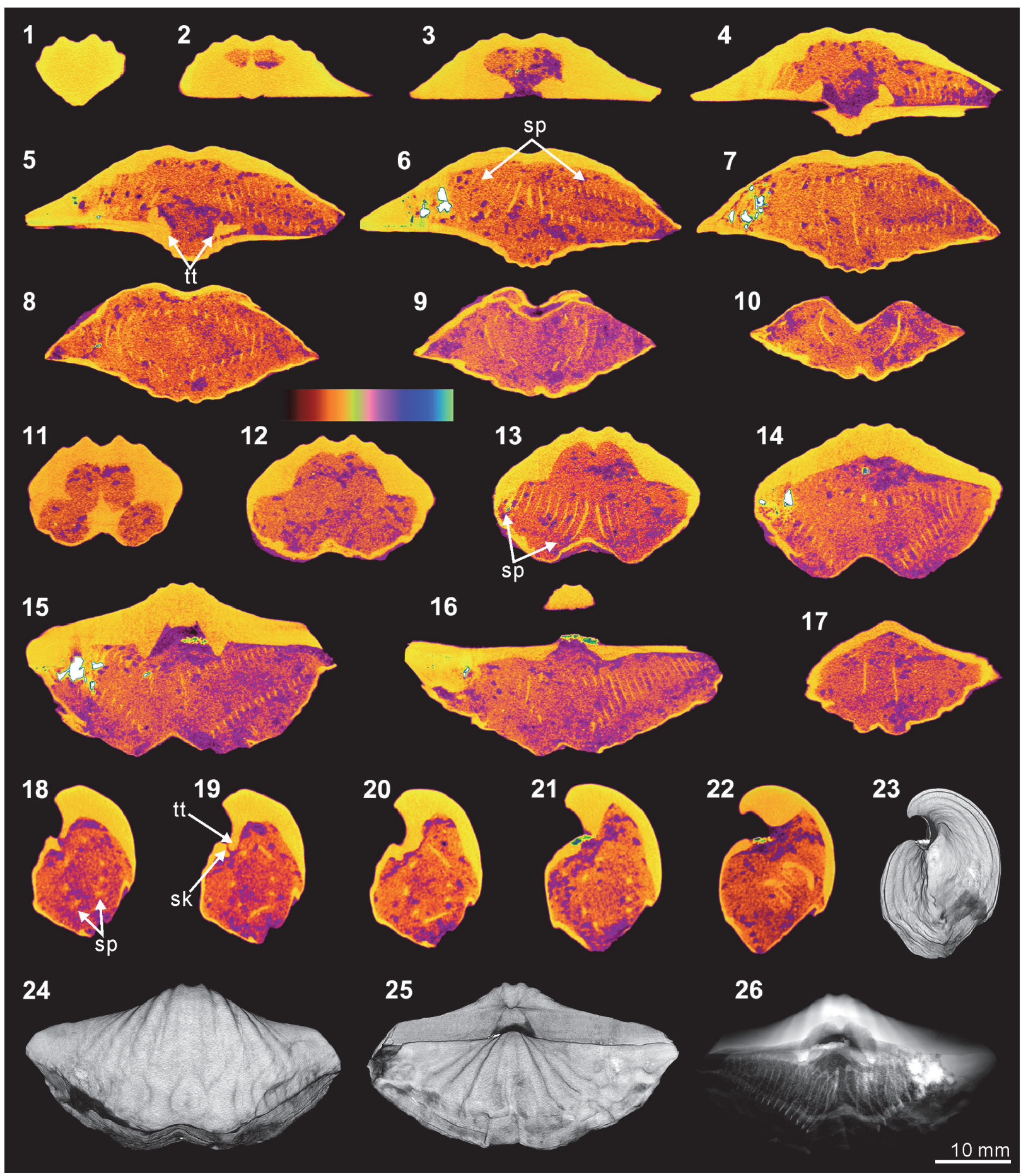

FIGURE 3. XMT result of Timaniella harkeri (GSC26406). 1-10, serial slices in the coronal plane (from posterior to anterior). 11-17, serial slices in the transverse plane (from ventral to dorsal). 18-22, serial slices in the sagittal plane (from lateral to middle). 23-25, lateral (23), ventral (24) and dorsal (25) views of the reconstructed 3-D model (external shell). 26, ventral view of the 3-D model in transparent mode. All the slice images were obtained under false-color lookup tables (Color 2 option in DataViewer). Abbreviations: tt, teeth; sp, spiralia; sk, socket. 


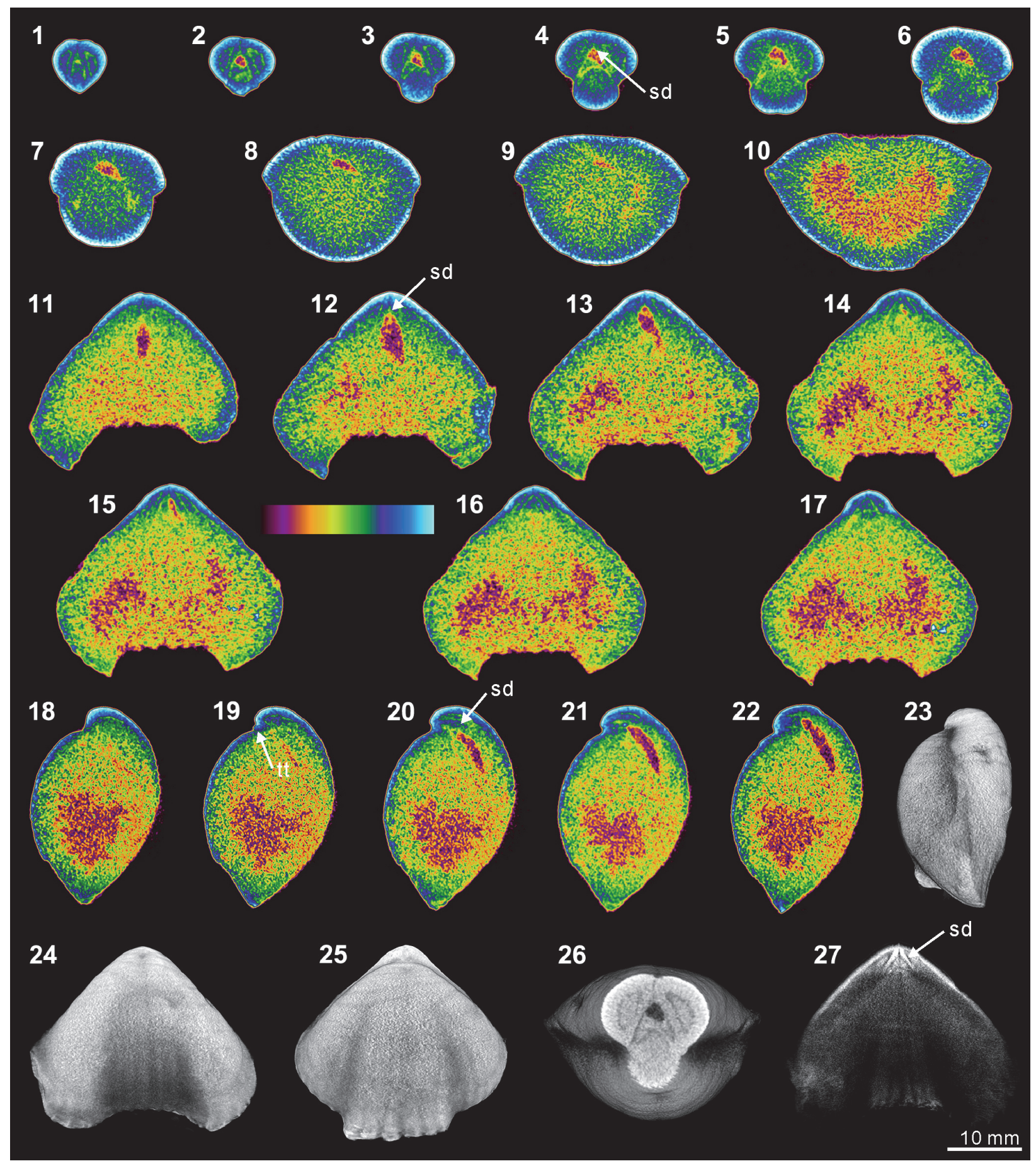

FIGURE 4. XMT result of Stenoscisma timorense (BS-2). 1-10, serial slices in the coronal plane (from posterior to anterior). 11-17, serial slices in the transverse plane (from ventral to dorsal). 18-22, serial slices in the sagittal plane (from lateral to middle). 23-25, lateral (23), ventral (24) and dorsal (25) views of the reconstructed 3-D model (external shell). 26, posterior view of the coronally sectioned 3-D model. 27, ventral view of the 3-D model in transparent mode. All the slice images were obtained under false-color lookup tables (Color 1 option in DataViewer). Abbreviations: sd, spondylium; tt, teeth. 
tion. Thin section and EDS results from BS-2 specimen indicate that the mineral composition of the brachiopod shell wall has been significantly altered by the formation of a thin partially replaced outer layer with silica and an underlying layer composed of fibrous to blocky calcite crystal formed by recrystallization in the mid-anterior part of the shell (Figure 1.9-12). The remaining part of the cavity between valves has been occluded by quartz cement. The overall luminescent shell in CL microscopic view (Figure 1.10,1.12) also indicates the existence of intense diagenetic alteration of the shell (Grossman et al., 1993, 2008).

\section{Carbonate Shell with Mixed Carbonate- siliciclastic Infilling}

This association is represented by two specimens, Cleiothyridina baracoodensis (Etheridge, 1903) (ML32) and Tylothyris transversa Roberts, 1971 (TeP). Both have comparable original calcitic shell mineralogy, and their enclosed sediments also consist of mixtures of carbonate and siliciclastic sediments. However, the textures and relative ratios of carbonate and siliciclastic sediments are different between the two specimens, resulting in a considerable difference in the quality of their XMT results.

The XMT 2-D sliced images of Cleiothyridina baracoodensis (ML32) demonstrate relatively distinct partition between the brachiopod shell and infilling sediment. The articulation of the two valves and cardinal flanges are also well delineated (Figure 5.5-6, 5.16-19, 5.23-26, 5.32), but other internal structures, which are expected in this species (e.g., brachidium), are mostly absent due to poor or non-preservation. Both the thin sections and EDS results suggest that specimen has retained its original calcitic shell structure and its microstructure. The infilling sediment includes peloids and clay minerals, but quartz grains of fine sand size are predominant (Table 3, Figure 1.13). Although the overall slightly luminescent brachiopod shell (Figure 1.16) appears to indicate no significant diagenesis on the shell, the presence of thin calcite layers within the shell is conspicuous, suggesting that the infilling cement has been fully recrystallized within the mid-anterior portion of the shell (Figure 1.1416).

The shell internal structures of Tylothyris transversa (TeP) are poorly recognized in any of its XMT sliced images. The boundary between the shell interiors and infilling material is only weakly visible at the posterior of the shell (Figure 6.1-2, $6.11,6.17-19)$. The only recognizable structure is a small portion of the spiralia, which extends posterolaterally, especially on the right side of the shell (Figure 6.5-6, 6.11-19, 6.23). Its thin sections and EDS results display a moderately thick, solely carbonate shell with infilling material composed of lime mud, calcite cement, and relatively large, radially arranged, siliceous crystals (Table 3 , Figure 1.17-18). The overall nonluminescent brachiopod shell (Figure 1.18-20) suggests that the shell has not suffered from diagenetic alteration, but the existence of large siliceous crystals within the infilling material indicates some degree of diagenesis.

\section{Carbonate Shell with Carbonate Infilling}

This association is represented by five specimens, all with their brachiopod shells and infillings predominantly made of carbonate. However, these specimens are distinguished by different texture of their infilling materials, with Spiriferina sp. (BS-1) characterized by calcite cement, Indospirifer sp. (3229) by lime mudstone, Cyrtospirifer whitneyi (Hall, 1858) (CD) by wackestone, Spiriferidae gen. sp. indet. (S1) by packstone, and Spiriferella loveni (Diener, 1903) (F8) by grainstone. As a result, the quality of their XMT results is very different.

The XMT result of Spiriferina sp. (BS-1) displays relatively well-recognized shell internal structures, although the distinction between the shell wall and infilling cement is obscure. Notably, both the 2-D sliced images and 3-D reconstructions of this specimen show strong teeth, high dental plates, and a long median septum on the ventral floor (Figure 7.2-11, 7.17-19, 7.23). In comparison, spiralia is not well distinguished in the 2-D images (Figure 7.7, 7.13-14, 7.18-19), but the same structure is more clearly displayed in the 3-D transparent model (Figure 7.23). Crura are weakly shown as parallel structures in a 2-D sliced image (Figure 7.14). Although this specimen is collected from the same lithological horizon with Stenoscisma timorense (BS-2) (Table 1), the preservation aspect of the shell and infilling material is considerably different. This specimen consists of relatively thin carbonate shell and enclosed calcite cement (Table 3 , Figure 1.5-8). The slightly luminescent shell in $C L$ microscopic view proves that the shell has suffered from some diagenetic alternations.

The XMT result of Indospirifer sp. (3229) also demonstrates some highly visible and distinct internal structures, but these structures potentially may be confused with some relatively large bioclasts which include some broken brachiopod shelly fragments, due to comparable mineralogy and grain size. Nevertheless, the 2-D sliced images and 3-D 


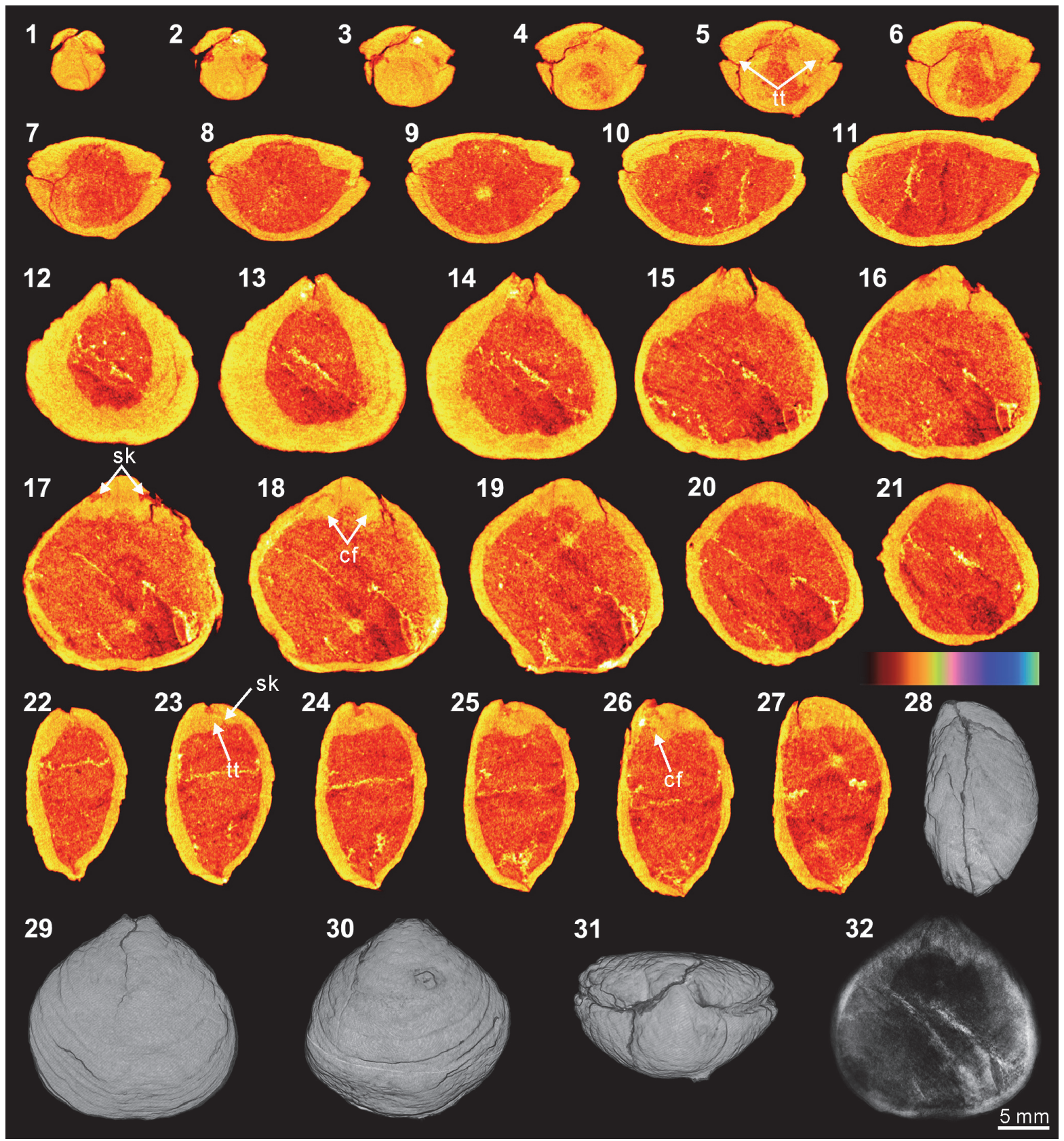

FIGURE 5. XMT result of Cleiothyridina baracoodensis (ML32). 1-11, serial slices in the coronal plane (from posterior to anterior). 12-21, serial slices in the transverse plane (from ventral to dorsal). 22-27, serial slices in the sagittal plane (from lateral to middle). 28-31, lateral (28), ventral (29), dorsal (30) and posterior (31) views of the reconstructed 3-D model (external shell). 32, ventral view of the 3-D model in transparent mode. All the slice images were obtained under false-color lookup tables (Color 2 option in DataViewer). Abbreviations: tt, teeth; sk, socket; cf, cardinal flanges.

transparent reconstruction model show the presence of strongly developed subparallel dental plates in this specimen (Figure 8.3-5, 8.9-10, 8.19, 8.24), as well as a dorsally convex large plate (Figure 8.6-8, 8.11-20, 8.24). Although this large dorsal plate could represent a hinge plate, this interpretation cannot be confirmed through the XMT images themselves because the plate is shown to be also connected laterally and anteriorly with some unidentified structures that possibly represent some broken shell fragments. In any case, both the thin sections and EDS results illustrate that the specimen has moderately thick carbonate brachiopod shell, and its internal cavity is predominantly 


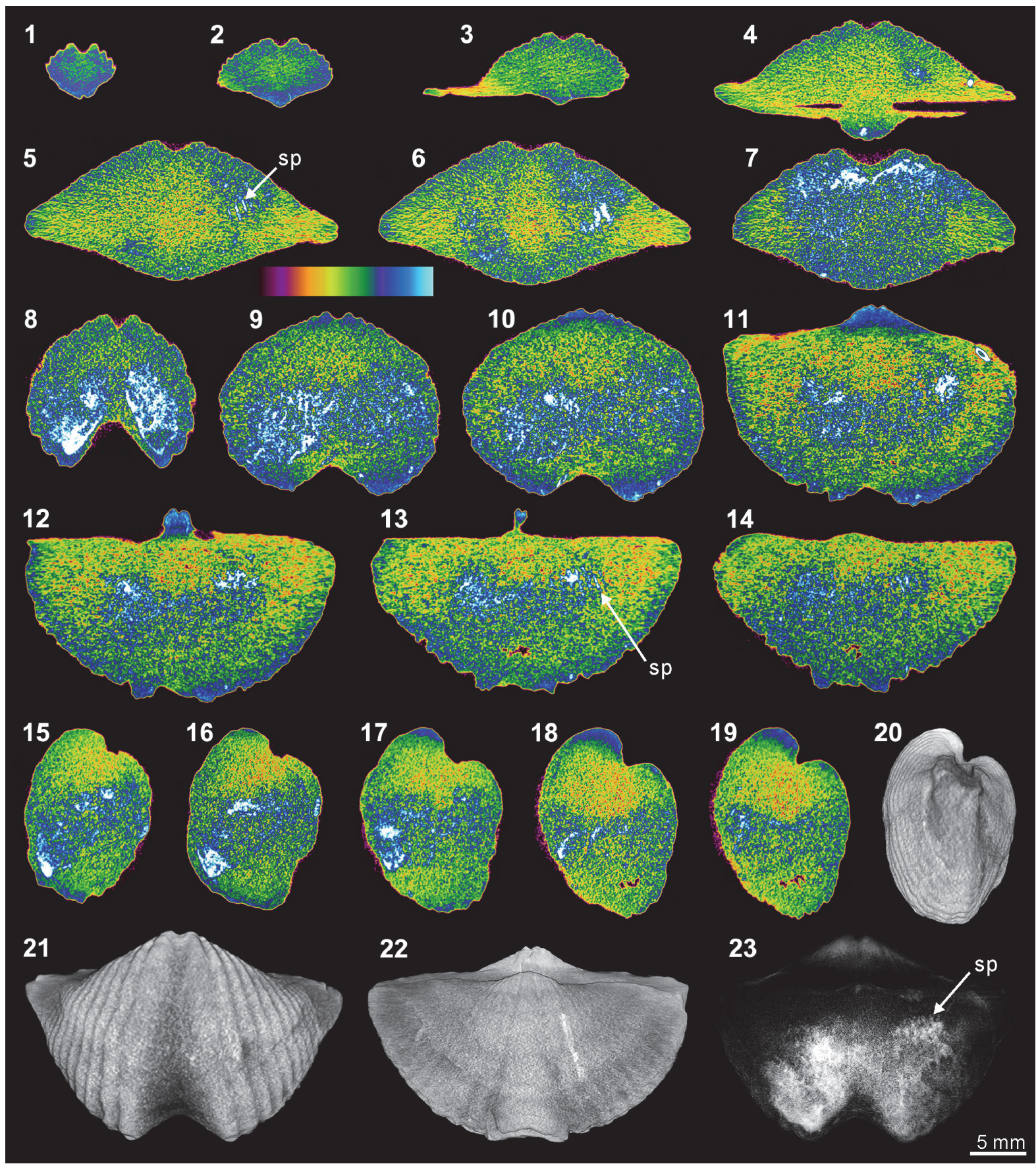

FIGURE 6. XMT result of Tylothyris transversa (TeP). 1-7, serial slices in the coronal plane (from posterior to anterior). 8-14, serial slices in the transverse plane (from ventral to dorsal). 15-19, serial slices in the sagittal plane (from lateral to middle). 20-22, lateral (20), ventral (21) and dorsal (22) views of the reconstructed 3-D model (external shell). 23, ventral view of the 3-D model in transparent mode. All the slice images were obtained under false-color lookup tables (Color 1 option in DataViewer). Abbreviation: sp, spiralia.

occupied by micrite with a very minor amount of clay minerals (Table 3, Figure 2.1-3). Several coarse skeletal grains, most probably representing broken fragments of the species' own structures, are clearly embedded among the muddy grains (Figure 2.1). The slightly luminescent brachiopod shell partially with luminescent region (Figure 2.24) suggests that the shell has experienced some diagenetic changes.

Overall the XMT result of Cyrtospirifer whitneyi (CD) shows low quality, indicated by poorly defined borders between the brachiopod shell and 


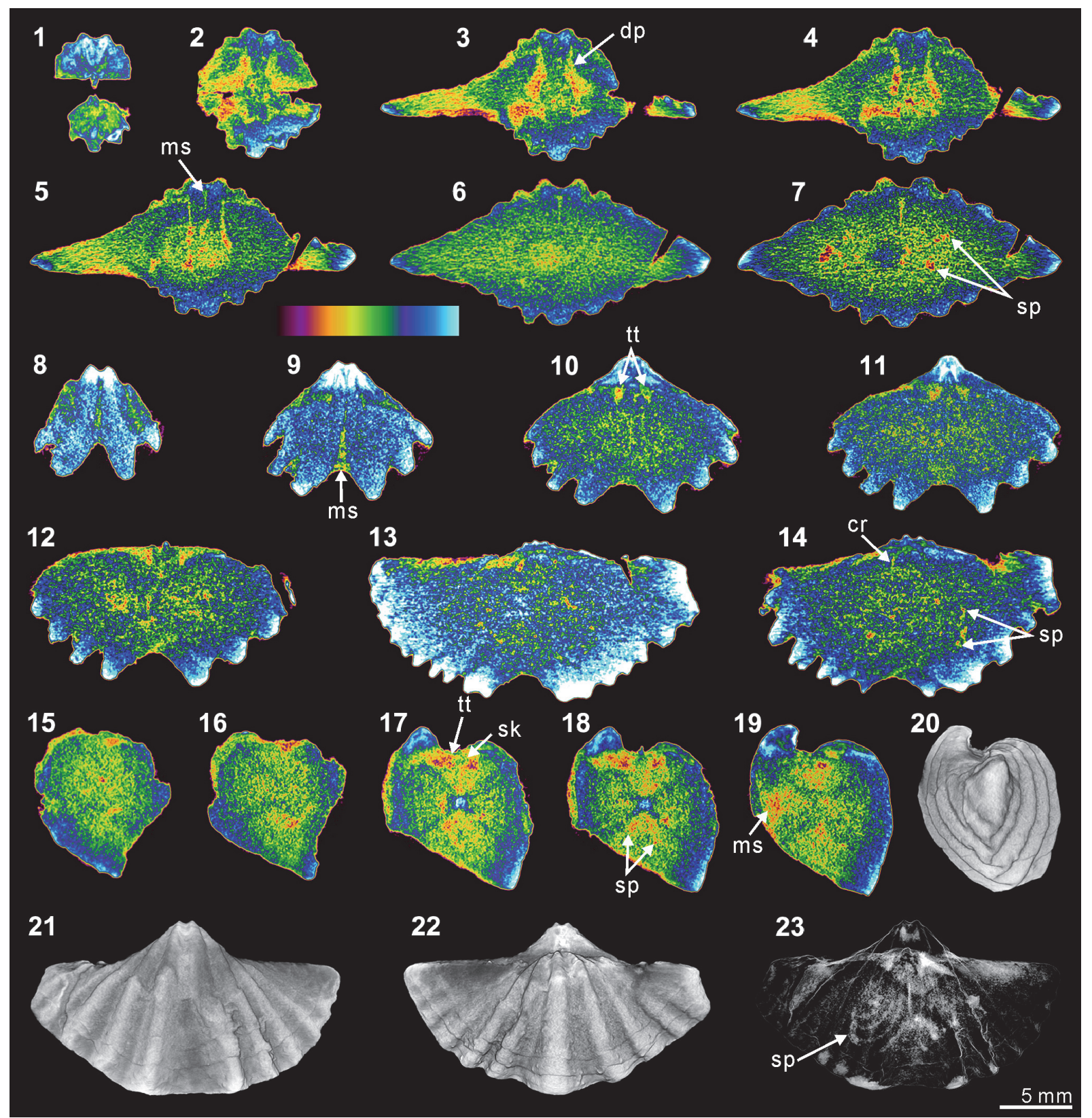

FIGURE 7. XMT result of Spiriferina sp. (BS-1). 1-7, serial slices in the coronal plane (from posterior to anterior). 8-14, serial slices in the transverse plane (from ventral to dorsal). 15-19, serial slices in the sagittal plane (from lateral to middle). 20-22, lateral (20), ventral (21) and dorsal (22) views of the reconstructed 3-D model (external shell). 23, ventral view of the 3-D model in transparent mode. All the slice images were obtained under false-color lookup tables (Color 1 option in DataViewer). Abbreviations: dp, dental plates; ms, median septum; sp, spiralia; tt, teeth; cr, crus; sk, socket.

its infilling sediment. Although some internal structures are visible, such as the dental structures comprising dental flanges and ventral adminicula (Figure 9.3-6, 9.12-16, 9.19-21, 9.29), no traces of dorsal interiors are revealed. The relatively thin brachiopod shell fully consists of carbonate, whereas its enclosed sediment is dominated by micrite with a small amount of clay materials and minor small shell fragments (e.g., bivalves and crinoid stems) (Table 3, Figure 2.5, 2.7). Both the shell and its infillings are luminescent in their $\mathrm{CL}$ microscopic views, suggesting that they have experienced significant diagenetic changes (Figure 2.5-8).

The XMT result of Spiriferidae gen. sp. indet. (S1) does not provide a clear distinction between 


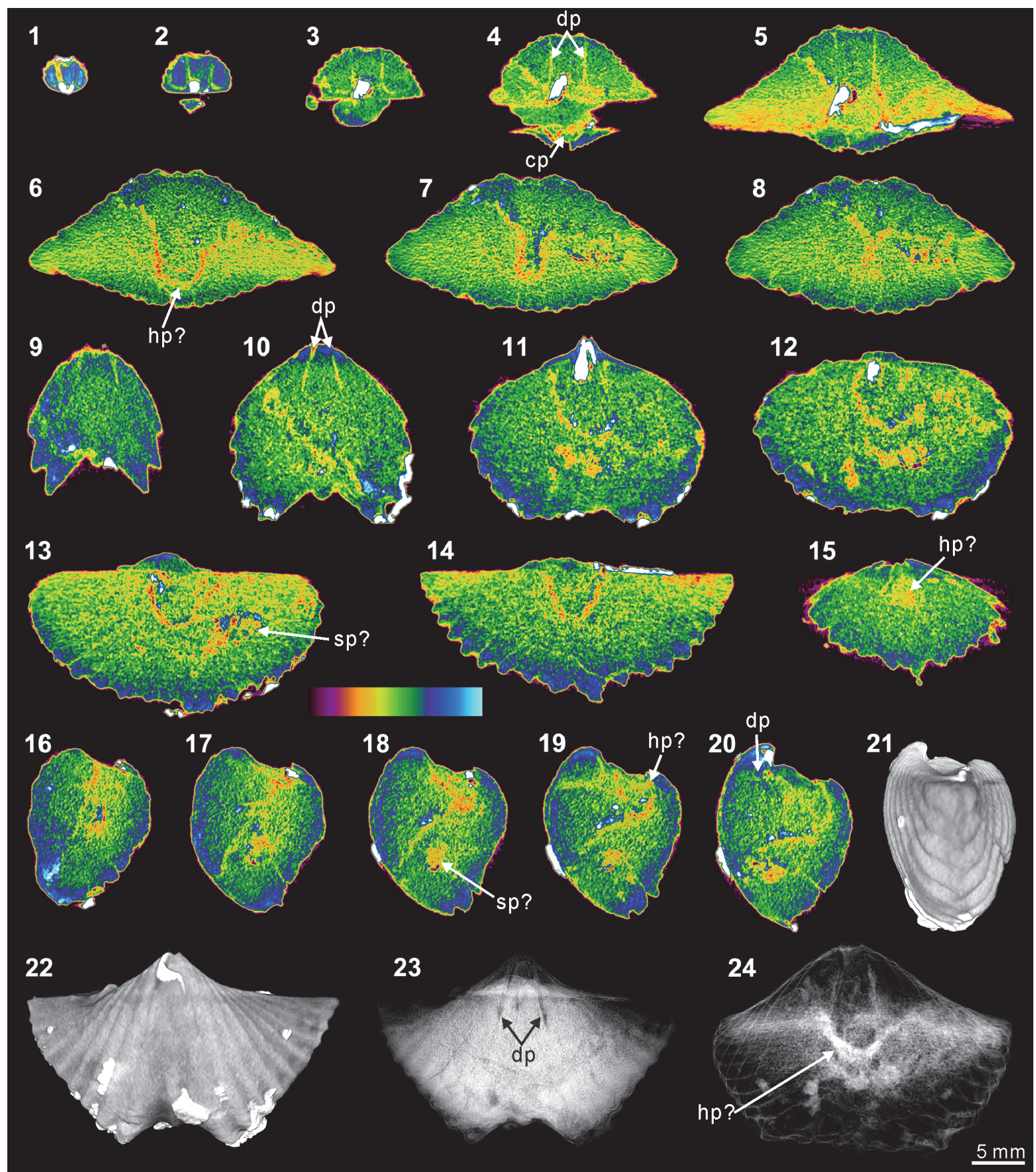

FIGURE 8. XMT result of Indospirifer sp. (3229). 1-8, serial slices in the coronal plane (from posterior to anterior). 9-15, serial slices in the transverse plane (from ventral to dorsal). 16-20, serial slices in the sagittal plane (from lateral to middle). 21-22, lateral (21) and ventral (22) views of the reconstructed 3-D model (external shell). 23-24, ventral (23) and ventroanterior (24) views of the 3-D model in transparent mode. All the slice images were obtained under false-color lookup tables (Color 1 option in DataViewer). Abbreviations: dp, dental plates; $\mathrm{cp}$, cardinal process; hp, hinge plate; sp, spiralia.

the brachiopod shell and its infilling sediment. However, the sliced images at the posterior part of the shell display a relatively well-defined boundary between the internal structures and enclosed sediment. In particular, the dental plates are highly visi- ble in both the 2-D images and 3-D reconstruction model (Figure 10.6-8, 10.16-18, 10.25). Its thin sections and EDS result show that both the brachiopod shell and infilling sediment are mainly composed of carbonate material, with the latter 


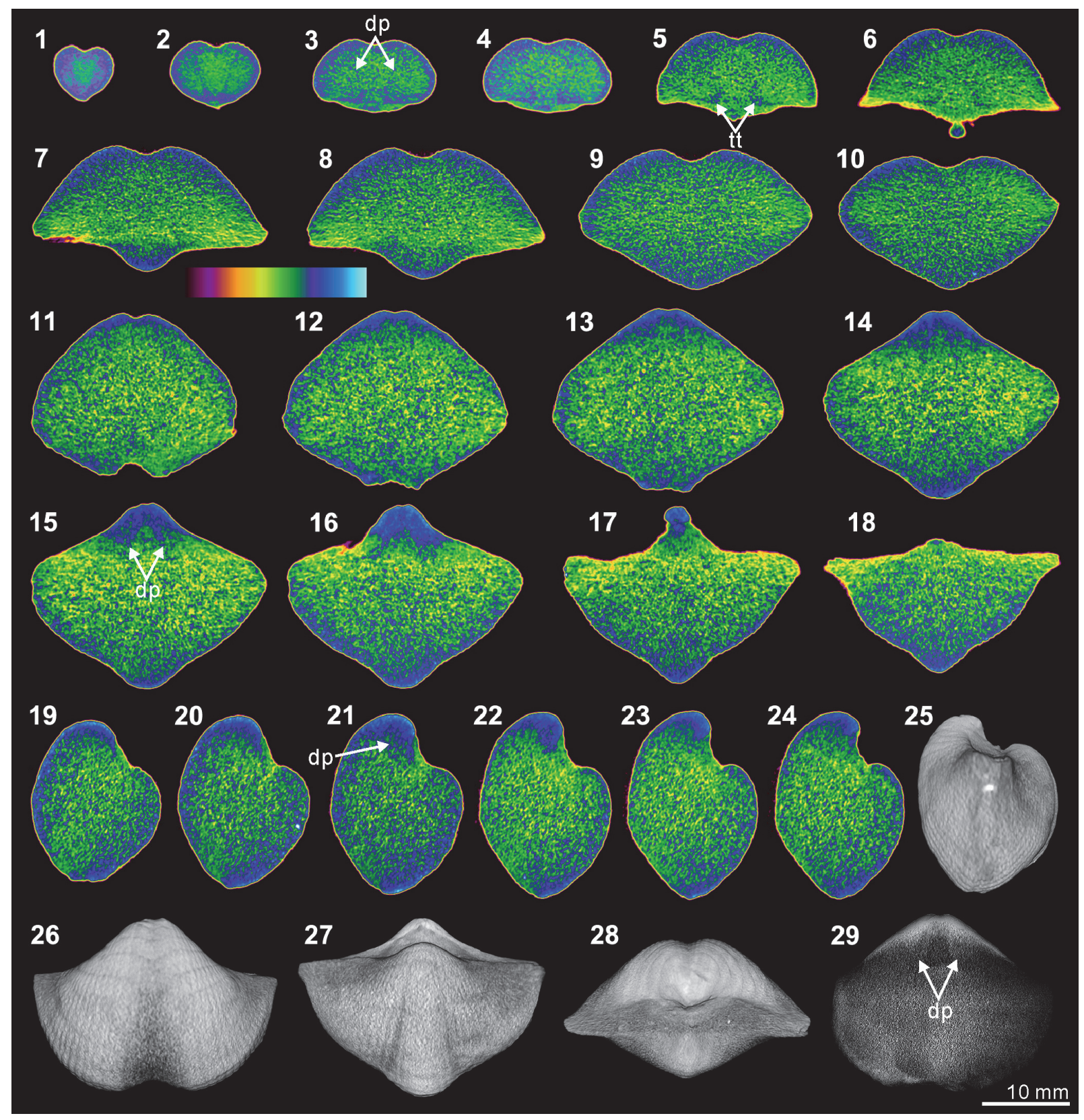

FIGURE 9. XMT result of Cyrtospirifer whitneyi (CD). 1-10, serial slices in the coronal plane (from posterior to anterior). 11-18, serial slices in the transverse plane (from ventral to dorsal). 19-24, serial slices in the sagittal plane (from lateral to middle). 25-28, lateral (25), ventral (26), dorsal (27) and posterior (28) views of the reconstructed 3-D model (external shell). 29, ventral view of the 3-D model in transparent mode. All the slice images were obtained under falsecolor lookup tables (Color 1 option in DataViewer). Abbreviations: dp, dental plates; tt, teeth.

mainly dominated by calcitic shelly grains. The results also illustrate the formation of a thin silicified layer between the brachiopod internal structures and infilling sediment (Table 3, Figure 2.911). The thin silicified layer appears to be prismatic, irregular in thickness and commonly discontinuous, which might cause the overall dull distinction between the shell and sediment inside of it.
The XMT result of Spiriferella loveni (F8) does not provide any trace of shell internal structure in either the 2-D slices or the 3-D reconstruction models, except for a vague border shown between the shell interior and infilling sediment. This specimen is composed of a strongly thickened carbonate shell and infilling grainstone composed mainly of assorted tiny brachiopod, bryozoan, and crinoid 


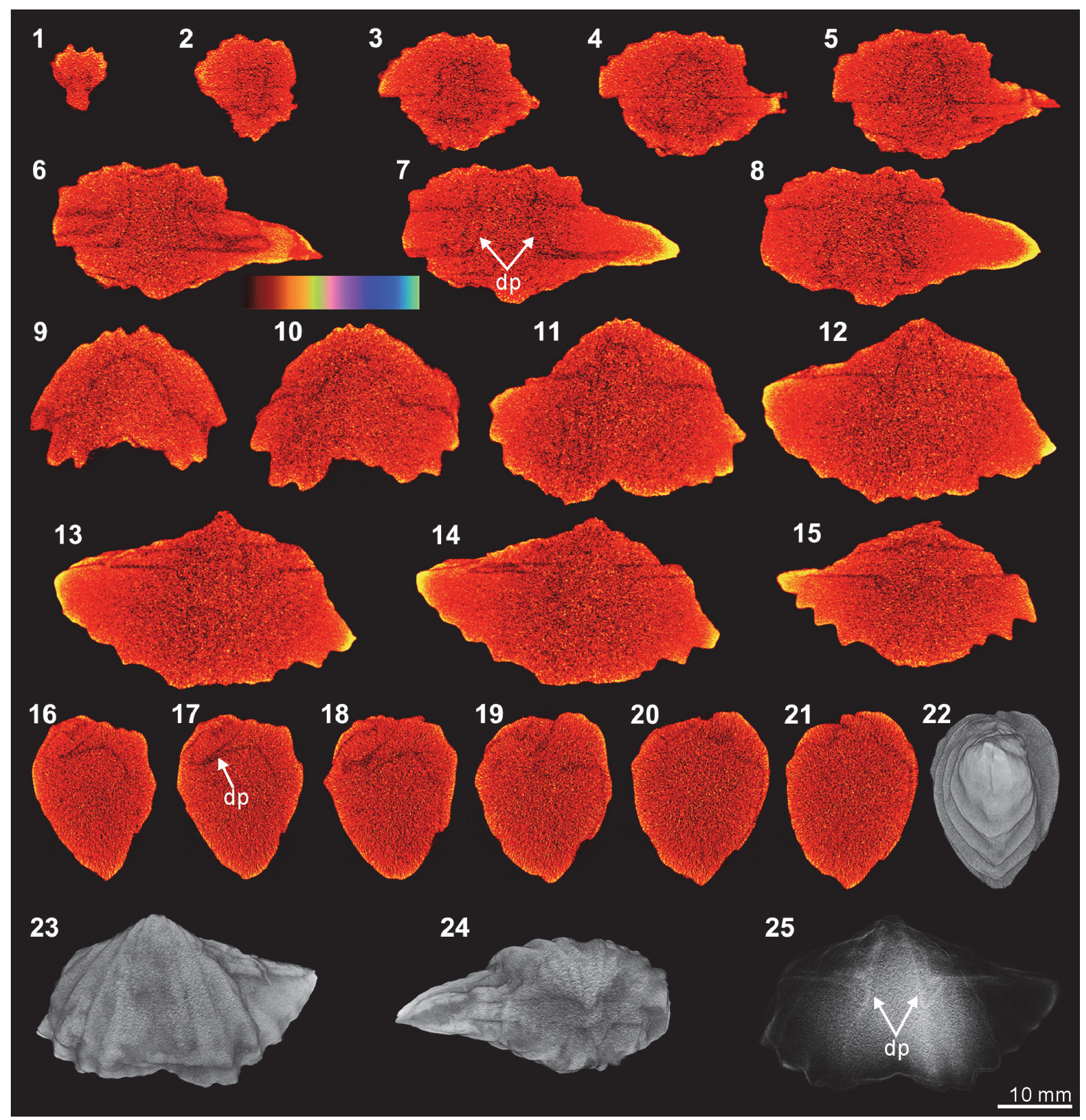

FIGURE 10. XMT result of Spiriferidae gen. sp. indet. (S1). 1-8, serial slices in the coronal plane (from posterior to anterior). 9-15, serial slices in the transverse plane (from ventral to dorsal). 16-21, serial slices in the sagittal plane (from lateral to middle). 22-24, lateral (22), ventral (23) and posterior (24) views of the reconstructed 3-D model (external shell). 25, ventral view of the 3-D model in transparent mode. All the slice images were obtained under false-color lookup tables (Color 1 option in DataViewer). Abbreviation: dp, dental plates.

shell fragments mixed with a small proportion of siliceous mineral grains (Table 3, Figure 2.13, 2.15). The brachiopod shell is variously luminescent in CL images (Figure 2.13-16) according to the shell layers.

\section{Shell and Infilling Both Silicified}

This association is represented by two specimens from a single horizon of the Qixia Formation,
China, Meekella sangzhiensis Liu and Zhao in Liu et al., 1982 (Q-1) and Tyloplecta nankingensis (Frech, 1911) (Q-2). Although both have gone through similar post-mortem physical/chemical processes, the quality of their XMT results shows significant disparity.

The XMT result of Meekella sangzhiensis (Q1 ) is characterized by weak visibility of the boundary between shell interiors and infilling cement, 
although some minor structure traces possibly representing the remains of closely spaced dental plates are recognizable at the interior of the ventral apical area (Figure 11.9-11, 11.13, 11.25). In particular, the 2-D images show that the internal space enclosed within the two valves is covered mostly by a uniform colour, suggesting that the composition and texture of the infilling cement is virtually identical to those of any shell internal structures of this species.

On the other hand, several distinctly recognizable internal features are observed in the XMT result of Tyloplecta nankingensis (Q-2), with its very thin-shelled appearance. The 2-D sliced images clearly exhibit its dorsal internal structures including a cardinal process (Figure 12.1-3, 12.10), adductor platforms (Figure 12.4-5, 12.12-13, 12.16-17), and a median septum (Figure 12.4, 12.18). Its 3-D transparent reconstruction model also shows a well-developed cardinal process with a weakly trifid form and laterally wide and thickened additional shafts (Figure 12.22). Muscle scars (probably adductors) are distinctly marked on the posterior of the ventral floor (Figure 12.4-9, 12.16$18,12.22)$.

Thin sections and EDS results of both specimens demonstrate that their shells and infillings have been completely silicified through severe diagenetic alteration (Table 3, Figure 2.17-20). However, the characteristics of the infilling material between the two specimens are different; the infilling of Meekella sangzhiensis (Q-1) contains microcrystalline quartz, whereas that of Tyloplecta nankingensis (Q-2) consists of quartz cement. Further, with regard to Tyloplecta nankingensis (Q-2), it was also revealed that a very thin void layer has been developed along the boundary between the shell part and infilling material.

\section{Full 3-D Reconstruction of Internal Structures}

XMT results, which present a clear distinction between shell internal structures and infilling material, enable us to reconstruct detailed 3-D models of shell internal structures. As an example, we have performed one such reconstruction model for Timaniella harkeri (GSC26406) (Figures 13-14). This specimen was chosen to demonstrate the considerable utility of XMT for future similar studies because it has produced by far the most superior high quality 2-D images in all of our XMT experiments (see Figure 3). This 3-D reconstruction model displays a very realistic and highly visible reproduction of key shell internal structures including the articulation along the hinge line, muscle field, and, most notably, the complete spiralia with all its whorls, as well as the distribution of striation and pits on the valve floors. In addition, this 3-D reconstruction model can be easily manipulated (e.g., rotation, magnification, and partial elimination) for more detailed examination (see Figure 14).

\section{DISCUSSION}

\section{Controlling Factors of XMT Results}

Our XMT results display a significant range of variability in the quality and resolution of the scanned images and therefore a varying degree of authenticity of these images in representing the original internal structures of the brachiopod specimens. The type of the brachiopod shells and their infilling materials plays a critical role as the single most important determinant for the quality and resolution of XMT images and reconstruction models. Our study demonstrates that sufficient contrast in mineral composition and texture between the brachiopod shell and its infilling is required to warrant the production of high-resolution XMT images and reconstructions. Especially, high-quality XMT images can be acquired from carbonate brachiopod shells embedded in highly siliceous materials. Of these cases, the sample of brachiopod shells still with their original calcitic mineralogy infilled with sandy quartz grains, tends to produce the highest quality XMT results characterized by sharply defined shell internal structures well distinguished from its adjacent sediment (Fig 3). A similar result has been suggested in Angiolini et al. (2010). By contrast, XMT outcomes from specimens with a high proportion of carbonate sediment display a much weaker distinction, as has also been reported by previous studies (Angiolini et al., 2010; Pakhnevich, 2010). Of note is the XMT result from Spiriferella loveni (F8) with infilling grainstone, which failed to reproduce any traces of internal structures, although its thick shell and dental structures are observed in its thin sections. The indistinctness in the XMT result of the specimen would be caused by the high similarity in mineral composition and texture between the brachiopod shell and the bioclasts in enclosed sediments. Another noticeable observation is that the XMT imaging contrast between carbonate brachiopod shell and its infilling sediment seems to increase as the proportion of coarser carbonate skeletal grains within the sediment decreases. This is evident by comparing the XMT result from Spirifella loveni (F8) with XMT images of Spiriferina sp. (BS-1) and 


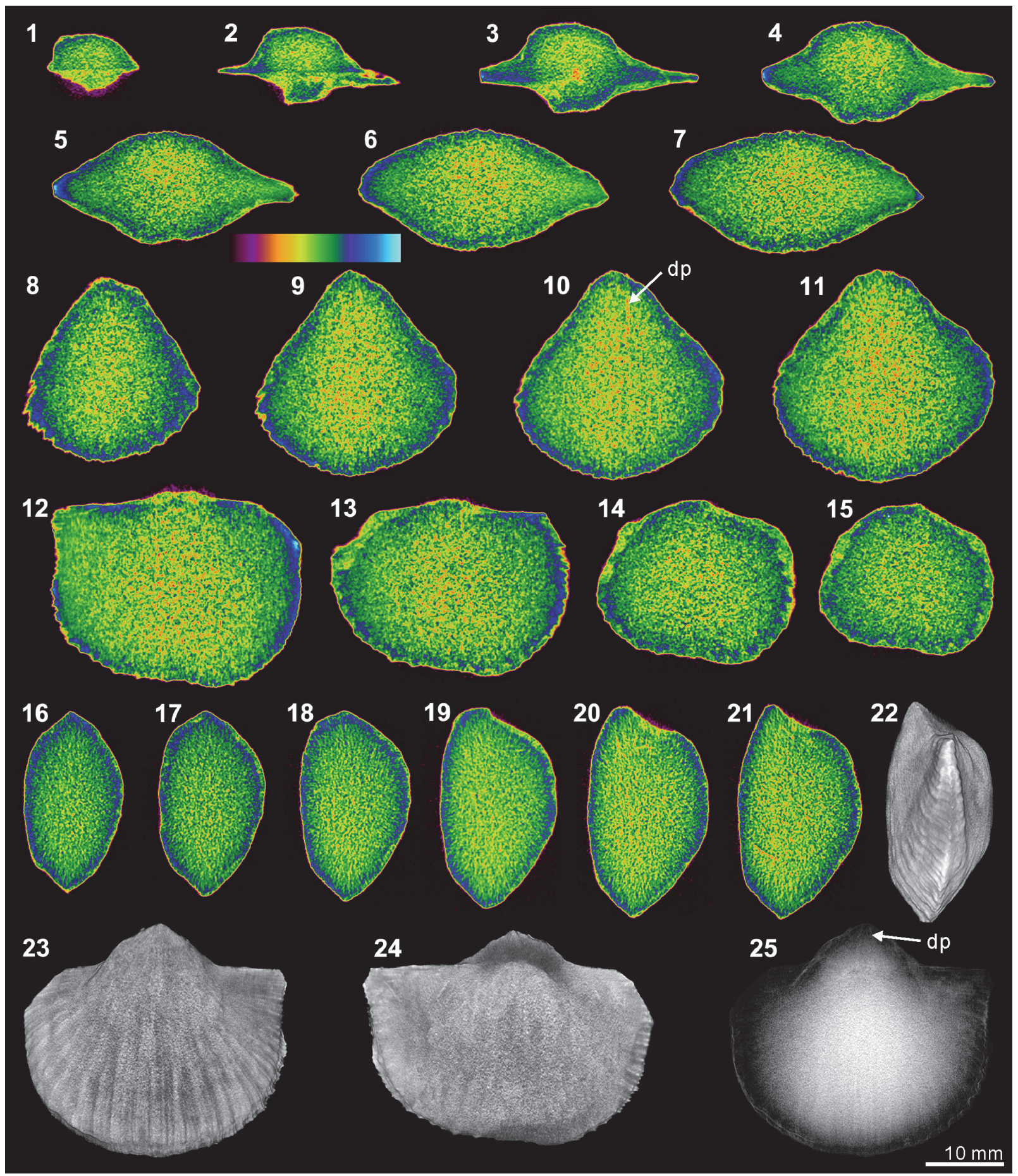

FIGURE 11. XMT result of Meekella sangzhiensis (Q-1). 1-7, serial slices in the coronal plane (from posterior to anterior). 8-15, serial slices in the transverse plane (from ventral to dorsal). 16-21, serial slices in the sagittal plane (from lateral to middle). 22-24, lateral (22), ventral (23) and dorsal (24) views of the reconstructed 3-D model (external shell). 25, ventral view of the 3-D model in transparent mode. All the slice images were obtained under false-color lookup tables (Color 1 option in DataViewer). Abbreviation: dp, dental plate. 


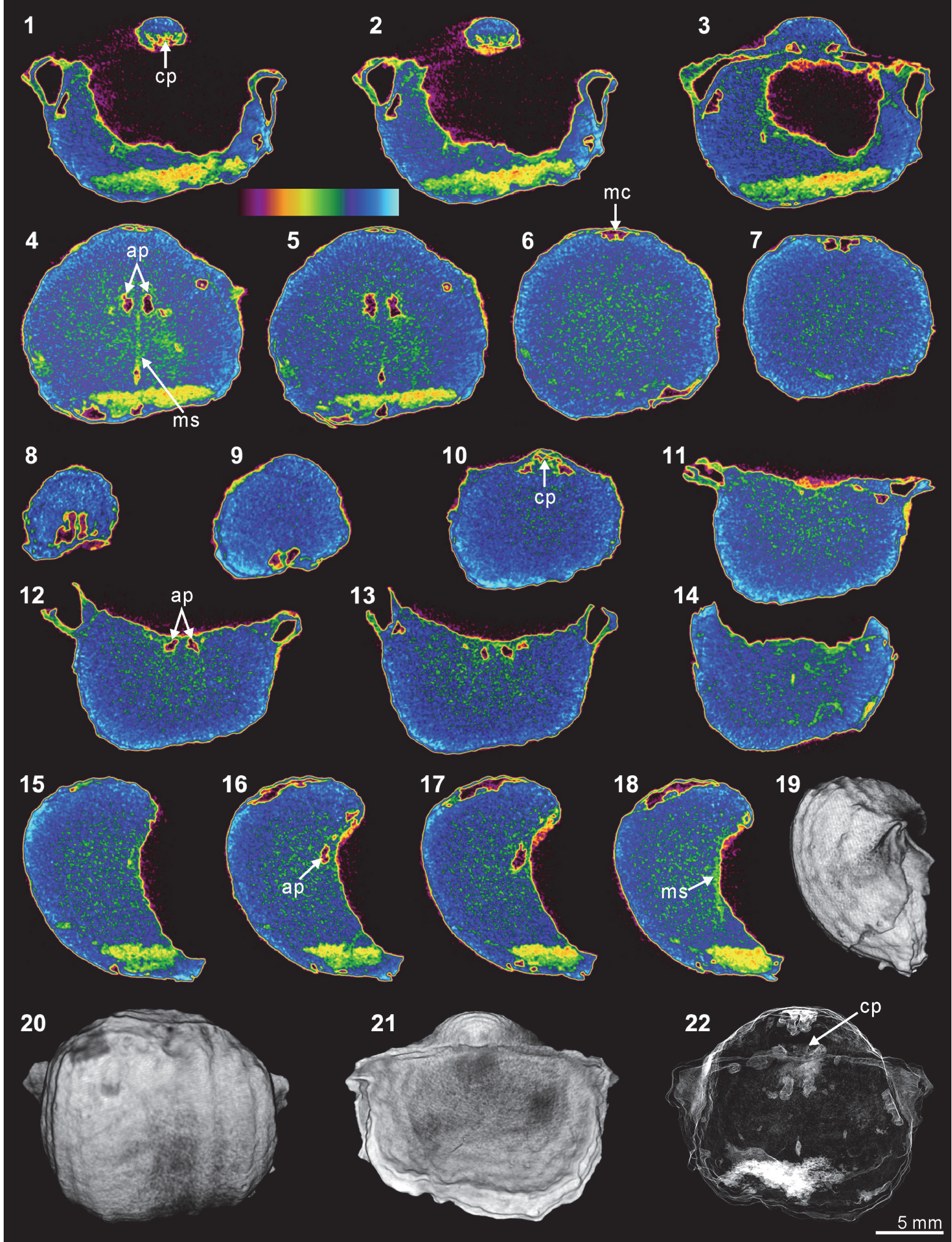

FIGURE 12. XMT result of Tyloplecta nankingensis (Q-2). 1-7, serial slices in the transverse plane (from dorsal to ventral). 8-14, serial slices in the coronal plane (from posterior to anterior). 15-18, serial slices in the sagittal plane (from lateral to middle). 19-21, lateral (19), ventral (20) and dorsal (21) views of the reconstructed 3-D model (external shell). 22, ventral view of the 3-D model in transparent mode. All the slice images were obtained under false-color lookup tables (Color 1 option in DataViewer). Abbreviations: $\mathrm{cp}$, cardinal process; ap, adductor platform; ms, median septum; mc, muscle scar. 


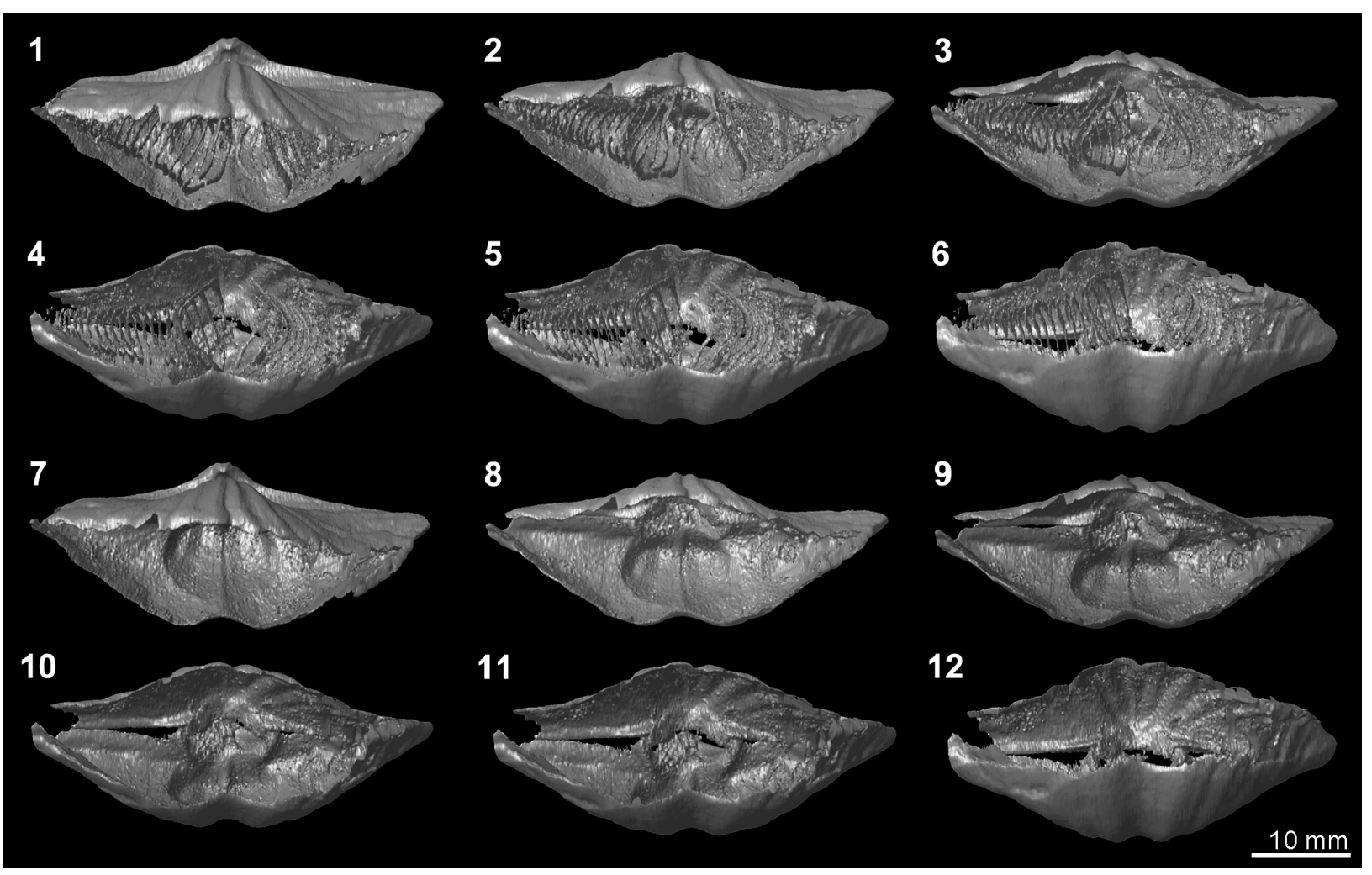

FIGURE 13. Three-dimensional reconstruction model of internal shell structures of Timaniella harkeri (GSC26406). 1-6, dorsal and anterior views of the whole shell interior through posteriorly continuous rotation. 7-12, dorsal and anterior views of shell interior without spiralia through posteriorly continuous rotation.

Indospirifer sp. (3229). The latter two specimens differ from the former only in the texture of their infillings (calcite cement and micrite), which has resulted in the successful reproduction of a large amount of internal structures (Figures 7 and 8 ), but none from Spiriferella loveni.

In addition to mineralogy and texture, diagenesis involving both brachiopod shell and its enclosed sediment appears to be significant in determining the XMT quality. In nature, diagenetic alteration is a common feature of sedimentary rocks and fossil shell material, although the degree of alteration may vary considerably in space and time. The analysis of thin sections confirmed that some of our brachiopod specimens have undergone significant diagenesis, reflected by partial to complete silicification and recrystallization either in brachiopod shells or infillings and, as a result, the quality of their XMT results varies accordingly. For example, Stenoscisma timorense (BS-2) is composed of carbonate brachiopod shell and enclosed quartz cement, which should facilitate high-quality reproduction of shell internal structures comparable to the XMT results of Timaniella harkeri (GSC26406) (Figure 3). However, the XMT result for Stenoscisma timorense (BS-2) are of low resolution and partly blurred (Figure 4), probably due to 1) recrystallization which has formed large calcite crystals and 2) the silicification of infilling cement. The XMT result of Spiriferidae gen. sp. indet. (S1) exhibits another aspect of diagenetic alteration. This specimen has undergone partial silicification indicated by a thin silicified layer along the boundary between the carbonate brachiopod shell and its infilling carbonate cement (Table 3, Figure 2.9-11). Consequently, the brachiopod internal structures buried within the shelly carbonate sediments are recognizable in the XMT result albeit with a low resolution.

Interestingly, different quality in the XMT result may have been caused by the same diagenetic effect. Meekella sangzhiensis (Q-1) and Tyloplecta nankingensis (Q-2) both have silicified shells and infillings, and were collected from the same horizon of the Qixia Formation, China. But, their XMT results are markedly different: the XMT result of the former displays only a weak distinction (Figure 11), whereas that of the latter exhibits a strong contrast between the shell and its infilling cement due to the existence of a thin void layer (Figure 12). Thus, it 


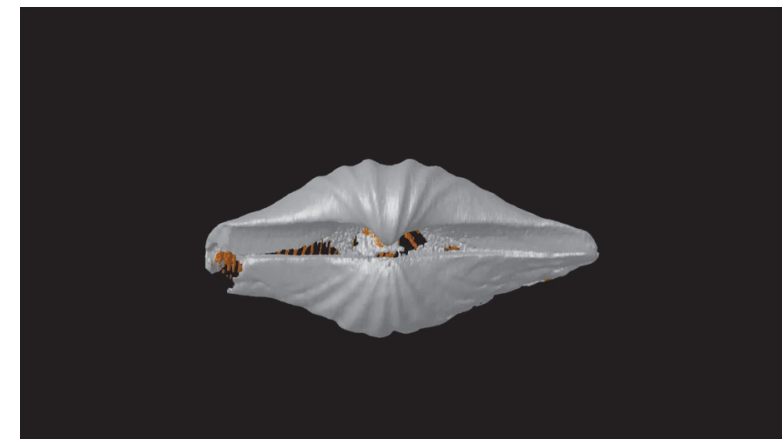

FIGURE 14. Three-dimensional rotational model (video) of Timaniella harkeri (GSC26406). For video see palaeo-electronica.org/content/2017/1891-xmt-on-brachiopod-fossils.

can be inferred that the quality of XMT results are subject not only to the degree of diagenetic alteration, but also to the difference in diagenetic processes experienced by the brachiopod shell and its infilling sediment, respectively. It is probable that the brachiopod shell and its infilling may have responded differently to the same diagenetic processes, resulting in a reduction or enhancement in the density of the material between the diagenetically altered shell and its enclosed material. A similar variability in the contrast between XMT results is also observed in Spiriferina sp. (BS-1) and Stenoscisma timorense (BS-2) (Figure 4 vs Figure 7). Although both specimens were collected from the same horizon of the Maubisse Formation in Timor, their shells and infillings display a considerable difference both in mineral composition and texture (Table 3, Figure 1.5-12). This case demonstrates that different extent of diagenetic alteration of brachiopod fossil shells observed may be caused by the difference in shell microstructure between the two different brachiopod taxa.

Another factor that may hinder the recognition of internal structures in XMT results is the presence of bioclasts scattered in the infilling sediments. These skeletal allochems could be composed of the same mineralogy of the brachiopod shell itself, and in some of the specimens (e.g., Indospirifer sp., Figure 8) they may produce a similar appearance to some of the brachiopod's internal structures, hindering the recognition of genuine internal structures of the brachiopod shell.

\section{Utility of XMT Applications for Brachiopod Research}

We have demonstrated that the quality of XMT results heavily depends on the mineralogical composition and texture of the brachiopod shells with respect to those of the materials enclosed by these brachiopod shells and the degree of their diagenetic alteration. Therefore, it is difficult to simply generalize the efficiency and effectiveness of the XMT technology for brachiopod research. However, it is clear from this study that XMT is a very powerful tool to reveal brachiopod internal structures embedded in rocks without the need to cut and eventually destroy both the rocks and the fossils. Except for one XMT result (Spiriferella loveni [F8]), all other experiments performed in this study have reproduced significant morphological information of brachiopod shell internal structures, which otherwise would not have been possible to acquire unless the brachiopod shells are mechanically sectioned.

XMT results are certainly more informative than outcomes from the traditional serial sectioning method, as they provide both 2-D sliced images in various axial planes as well as complete 3-D reconstructions as a final product. Particularly, in cases where there is sufficient contrast between the shell and its infilling, the XMT results can produce superior high-resolution 3-D models of shell internal structures. In these cases, the 3-D reconstructions would represent virtual replica of the original fossils, some of which are so detailed that they even show the micro-ornamentation within the shell interior with exceptional high resolution (Figures 13-14). Similar 3-D reconstructions of brachiopod internal structures have been attempted with mechanically prepared serial sections, also displaying considerably detailed outcomes (Sutton et al., 2005; Schemm-Gregory and Sutton, 2010; Schemm-Gregory, 2014); but their resolutions do not reach those from XMT results, and they do not reproduce any micro-ornamentations.

Even in cases where the XMT results did not display a distinct contrast between the whole brachiopod shell and its infilling material, partial traces of shell internal structures are still visible, helping to identify and characterize the shell internal structures (Figures 6, 9-11). In particular, our XMT results show that internal structures in the posterior part of the shell, commonly represented by dental and hinge structures, are recognizable by XMT in most cases, although their full reconstruction would be difficult due to the poor quality. As these internal structures are widely regarded as crucial for brachiopod taxonomy and phylogeny, XMT technology clearly has a significant role to play for enhancing the study of brachiopods.

With the rapid improvement of modern technology, XMT devices and SRXTM are also quickly being upgraded, which not only promises to further 
increase resolutions, but also the potential to reproduce, with high resolution, fossil structures embedded even in rocks with lower contrast between fossils and their enclosed materials, as well as the potential for these technologies to be applied to larger fossil specimens. Further, with the expansion of X-ray tomographic technologies to many areas of science, they are also becoming more accessible to palaeontologists, truly marking the beginning of a new era for virtual palaeontology.

\section{CONCLUSIONS}

XMT experiments herein applied to 11 Palaeozoic brachiopod specimens reveal that the type of the fossil shells and their infillings both play a critical role in determining the quality and resolution of XMT images and reconstructions. The production of high-quality XMT images requires sufficient contrast in mineral composition and texture between the shell and its infilling material. In particular, the XMT results acquired from carbonate shells infilled with highly siliceous materials generally display a high distinction of internal structures. Diagenetic alteration is also shown to be another significant factor adversely affecting the XMT results. Both silicification and recrystallization of the shell and/or the enclosed material, caused by diagenesis, tend to diminish the quality of the XMT results although the degree of this effect is clearly dependent on the degree of the diagenetic alteration and also on the difference in diagenetic processes between the shell and the adjacent sediment. As a minor factor, the inclusion of bioclasts scattered in the infilling sediment may hinder the recognition of internal structure in XMT results. Despite the variation in the quality of the images, XMT and SRXTM techniques are considered to be novel and powerful tools for the investigation of brachiopod internal morphology.

\section{ACKNOWLEDGEMENTS}

The authors would like to thank S.-H. Hong at the Dental Research Institute of Seoul National University for helping us with running SkyScan 1172 system. We are grateful to A.V. Pakhnevich for valuable advices on XMT experiments. Thanks are extended to J.B. Waterhouse, E.A. Weldon and J. Woo for providing insightful comments to improve the manuscript, to D.J. Lee and H.-G. Kim for helping in preparation of thin sections, and to T.$\mathrm{H}$. Kim for help in EDS analysis. We are also indebted to $\mathrm{C}$. Haug and two anonymous reviewers for their useful comments and suggestions. Financial support was provided by the Korea Polar Research Institute project PE17160 to SL, TYSP, and JRO; by the Australian Research Council through grant DP150100690 to GRS; by Deakin University to SL and GRS.

\section{REFERENCES}

Abel, R.L., Laurini, C.R., and Richter, M. 2012. A palaeobiologist's guide to 'virtual' micro-CT preparation. Palaeontologia Electronica, 15.2.6T:1-17; palaeoelectronica.org/content/issue-2-2012-technical-articles/233-micro-ct-workflow

Alvarez, F. and Brunton, C.H.C. 2008. On the reliability of reconstructing and comparing brachiopod interiors and their morphological variations based solely on serial sections. Proceedings of the Royal Society of Victoria, 120:58-74.

Angiolini, L., Barberini, V., Fusi, N., and Villa, A. 2010. The internal morphology of fossil brachiopods under X-ray computerised tomography (CT), p. 7-8. In Shi, G.R., Percival, I.G., Pierson, R.R., and Weldon, E.A. (eds.), 6th International Brachiopod Congress, February 1-5, 2010, Melbourne, Australia. Geological Society of Australia, Abstract No. 95. Geological Soceity of Australia, Sydney.

Archbold, N.W. and Bird, P.R. 1989. Permian Brachiopoda from near Kasliu Village, West Timor. Alcheringa, 13:103-123.

Bamber, E.W. and Waterhouse, J.B. 1971. Carboniferous and Permian stratigraphy and paleontology, northern Yukon Territory, Canada. Bulletin of Candian Petroleum Geology, 19:29-250.

Barbin, V. and Gaspard, D. 1995. Cathodoluminescence of recent articulate brachiopod shells. Implications for growth stages and diagenesis evaluation. Geobios, 18:39-45.

Błażejowski, B., Binkowski, M., Bitner, M.A., and Gieszcz, P. 2011. X-ray Microtomography (XMT) of Fossil Brachiopod Shell Interiors for Taxonomy. Acta Palaeontologica Polonica, 56:439-440.

Charlton, T.R., Barber, A.J., Harris, R.A., Barkham, S.T., Bird, P.R., Archbold, N.W., Morris, N.J., Nicoll, R.S., Owen, H.G., Owens, R.M., Sorauf, J.E., Taylor, P.D., Webster, G.D., and Whittaker, J.E. 2002. The Permian of Timor: stratigraphy, palaeontology and palaeogeography. Journal of Asian Earth Sciences, 20:719774.

Cunningham, J.A., Rahman, I.A., Lautenschlager, S., Rayfield, E.J., and Donoghue, P.C.J. 2014. A virtual world of paleontology. Trends in Ecology \& Evolution, 29:347-357.

Day, J. 1988. The brachiopod succession of the Late Givetian-Fransnian of low, 303-325. In McMillan, N.J., Embry, A.F., and Glass, D.J. (eds.), Devonian of the World, Volume III. Canadian Society of Petroleum Geologists Memoir 14. Friesen \& Sons, Canada. 
Diener, C. 1903. Permian Fossils of the Central Himalayas. Memoirs of the Geological Survey of India, Palaeontologia Indica (Series 15), 1(5):1-204.

Frech, F. 1911. Das Obercarbon Chinas, Die Dyas, p. 97-202, 243-266. In von Richthofen, F. (ed.), China 5. Dietrch Reimer, Berlin.

Etheridge, R. 1903. Description of Carboniferous fossils the Gascoyne District, Western Australia. Bulletin of Geological Survey of Western Australia, 10:1-41.

Gaspard, D. 2013. X-ray computed tomography: A promising tool to investigate the brachiopod shell interior. Effects on 3D modelling and taxonomy. Comptes Rendus Palevol, 12:149-158.

Gobbett, D.J. 1964. Carboniferous and Permian brachiopods of Svalbard. Norsk polarinstitutt Skrifter, 127:1201.

Grossman, E.L., Mii, H.S., and Yancey, T.E. 1993. Stable isotopes in late Pennsylvanian brachiopods from the United States: implications for Carboniferous paleoceanography. Geological Society of America Bulletin, 105:1284-1296.

Grossman, E.L., Yancey, T.E., Jones, T.E., Bruckschen, P., Chuvashov, B., Mazzullo, S.J., and Mii, H.S. 2008. Glaciation, aridification, and carbon sequestration in the Permo-Carboniferous: the isotopic record from low latitude. Palaeogeography, Palaeoclimatololgy, Palaeoecology, 268:222-233.

Hagadorn, J.W., Whiteley, T., and Nealson, K.H. 2001. 3D imaging of pyritized soft tissues in Paleozoic Konservat-Lagerstatten, p. 430-431. In (editor unknown), Geological Society of America Annual Meeting, November 5-8, 2001, Boston, Massachusetts, USA, Geological Society of America, Boulder.

Halamski, A.T., Bitner, M.A., Kaim, A., Kolar-Jurkovšek, T., and Jurkovšek, B. 2015. Unusual brachiopod fauna from the Middle Triassic algal meadow of Mt. Svilaja (Outer Dinarides, Croatia). Journal of Paleontology, 89:553-575.

Hall, J. 1858. Palaeontology of lowa, p. 473-724. In Hall, J. and Whitney, J.D. (eds.), Report of the Geological Survey of the State of lowa: Embracing the Results of Investigations made during Portions of the Years 1855, 56, and 57, Vol. 1, Part 2. C. van Benthuysen, Albany.

Hayasaka, I. and Gan, S. 1940. A note on Camarophoria 'purdoni' from the Permian of Timor. Journal of the Geological Society of Japan, 47:127-132.

Kaloyan, A.A., Kovalenko, E.S., Pakhnevich, A.V., Podurets, K.M., Rozhnov, S.V., and Somenkov, V.A. 2014. Synchrotron and neutron tomography for the investigation of paleontological objects. Journal of Surface Investigation - X-ray, Synchrotron and Neutron Techniques, 8:1903-1099.

Liu, Z., Tan, Z., and Ding, Y. 1982. Brachiopoda, p. 172216. In The Palaeontological Atlas of Hunan. Geological Publishing House, Beijing.

Motchurova-Dekova, N. and Harper, D. 2010. Synchrotron radiation $\mathrm{X}$-ray tomographic microscopy (SRXTM) of brachiopod shell interiors for taxonomy:
Preliminary report. Annales Géologique De La Péninsule Balkanique, 71:109-117.

Nakamura, K., Sakagami, S., Okimura, Y., Tazawa, J.-I., Igo, H., Kumon, F., Kawamura, T., Ezaki, Y., Kano, A., and Keilen, H.B. 1992. Preliminary report of stratigraphical study on the Upper Carboniferous-Upper Permian, p. 1-36. In Nakamura, K. (ed.), Investigations on the Upper Carboniferous-Upper Permian Succession of West Spitsbergen 1989-1991. Hokkaido University, Sapporo.

Pakhnevich, A.V. 2007. A microtomohraphic study of the internal structure of holotypes of brachiopods, p. 3132. In Rozanov, A.Yu., Lopatin, A.V., Parkhaev, P.Yu., and Rozhnov, S.V. (eds.), Modern Paleontology: Classical and New Methods: 4th All-Russia Scientific School for Young Scientists-Paleontologists, October 15-17, 2007. Paleontological Institute RAS, Moscow.

Pakhnevich, A.V. 2009. On effectiveness of micro-CT research of paleontological objects, p. 127-141. In Rozanov, A.Yu., Lopatin, A.V., and Parkhaev, P.Yu. (eds.), Modern Paleontology: Classical and New Methods 2009. Paleontological Institute RAS, Moscow.

Pakhnevich, A.V. 2010. Study of fossil and recent brachiopods, using a skyscan 1172 X-ray microtomograph. Paleontological Journal, 44:1217-1230.

Pakhnevich, A.V. 2011. The type specimens of the Holocene brachiopod Diestothyris frontalis (Middendorff, 1849). Memoir of the Association of Australasian Palaeontologists, 41:269-272.

Pakhnevich, A.V. 2014. On the micro-CT investigation of the type specimens for example brachiopods, p. 189192. In (editor unknown), Bruker micro-CT User Meeting, May 5-8, 2014, Ostend, Belgium. Bruker micro-CT, Kontich.

Pakhnevich, A.V. 2017. A reconstruction of the lophophore of Devonian rhynchonellids (Brachiopoda) by using X-ray micro-CT. Paleontological Journal, 51:143-154.

Perez-Huerta, A., Cusack, M., McDonald, S., Marone, F., Stampanoni, M., and MacKay, S. 2009. Brachiopod punctae: a complexity in shell biomineralisation. Journal of Structural Biology, 167:62-67.

Popp, B.N., Anderson, T.F., and Sandberg, P.A. 1986. Brachiopods as indicators of original isotopic compositions in some Paleozoic limestones. Geological Society of America Bulletin, 97:1262-1269.

Rahman, I.A. and Smith, S.Y. 2014. Virtual paleontology: Computer-aided analysis of fossil form and function. Journal of Paleontology, 88:633-635.

Roberts, J. 1971. Devonian and Carboniferous brachiopods from the Bonaparte Gulf Basin, Northwestern Australia. Bureau of Mineral Resources, Bulletin of Australian Geology and Geophysics, 122:1-319.

Sandy, M.R. 1986. Brachiopod systematics and the transverse serial sectioning method: some recommendations for this technique and clarification of a taxonomic problem assisted by this method, p. 143151. In Racheboeuf, P. and Emig, C.C. (eds.), Les 
Brachiopodes Fossiles et Actuels: Actes du 1er Congres International sur les Brachiopodes, Brest 1985. Biostratigraphie du Paleozoique 4. Université de Bretagne occidentale, France.

Schemm-Gregory, M. 2014. A new Givetian athyridid species from Northwest Africa discovered by threedimensional reconstruction of shell morphology of internal molds. Journal of Paleontology, 88:708-718.

Schemm-Gregory, M. and Sutton, M. 2010. First report of brachiopod-brachiopod endoparasitism. Lethaia, 43:112-115.

Seidel, R. and Lüter, C. 2014. Overcoming the fragility X-ray computed micro-tomography elucidates brachiopod endoskeletons. Frontiers in Zoology, 11:65. doi : 10.1186/s12983-014-0065-x

St. Joseph, J.K.S. 1937. On Camarotoechia borealis (von Buch 1834, ex. Schlotheim 1832). Geological Magazine, 74:33-48.

Streng, M., Butler, A.D., Peel, J.S., Garwood, R.J., and Caron, J.B. 2016. A new family of Cambrian rhynchonelliformean brachiopods (Order Naukatida) with an aberrant coral-like morphology. Palaeontology, 59:269-293.

Sutton, M.D. 2008. Tomographic techniques for the study of exceptionally preserved fossils. Proceedings of the Royal Society B (Biological sciences), 275:1587-1593.
Sutton, M.D., Briggs, D.E.G., Siveter, D.J., and Siveter, D.J. 2005. Silurian brachiopods with soft-tissue preservation. Nature, 436:1013-1015.

Sutton, M.D., Rahman, I.A., and Garwood, R.J. 2014. Techniques for Virtual Palaeontology. Wiley, Oxford.

Thomas, G.A. 1958. The Permian Orthotetacea of Western Australia. Bureau of Mineral Resources, Bulletin of Australian Geology and Geophysics, 39:1-159.

Tomašových, A. and Farkaš, J. 2005. Cathodoluminescence of Late Triassic terebratulid brachiopods: implications for growth patterns. Palaeogeography, Palaeoclimatololgy, Palaeoecology, 216:215-233.

Waterhouse, J.B. and Waddington, J. 1982. Systematic descriptions, paleoecology and correlations of the Late Paleozoic subfamily Spiriferellinae (Brachiopoda) from the Yukon Territory and the Canadian Arctic Archipelago. Bulletin of Geological Survery of Canada, 289:1-57.

Westbroek, P. 1969. The interpretation of growth and form in serial sections through brachiopods, exemplified by the trigonirhynchiid septalium. Palaeontology, 12:321-332.

Williams, A. 2002. Coordinating author's preface, p. xxvixxx. In Kaesler, R.L. (ed.), Treatise on Invertebrate Paleontology, Part H. Brachiopoda (Revised) 4 Rhynchonelliformea (part). Geological Society of America and University of Kansas Press, Boulder, Colorado and Lawrence, Kansas, 1-807. 